\title{
FIXAÇÃO DE FRUTOS DE LIMEIRA ÁCIDA 'TAHITI', SUA RELAÇÃO COM O ACÚMULO DE GRAUS-DIAS E A APLICAÇÃO DE ÁCIDO GIBERÉLICO
}

\author{
MARCEL BELLATO SPÓSITO \\ Engenheiro Agrônomo
}

Orientador: Prof. Dr. FRANCISCO DE ASSIS ALVES MOURÃO FILHO

Dissertação apresentada à Escola Superior de Agricultura "Luiz de Queiroz", Universidade de São Paulo, para a obtenção do título de Mestre em Agronomia, Area de Concentração: Fitotecnia

\author{
PIRACICABA \\ Estado de São Paulo - Brasil \\ Outubro - 1999
}


Dados Internacionais de Catalogação na Publicação (CIP) DIVISÃo DE BIBLIOTECA E DOCUMENTAÇĀO - Campus “Luiz de Queiroz"/USP

Spósito, Marcel Bellato

Fixaçāo de frutos de limeira ácida "Tahiti", sua relaçāo com o acúmulo de grausdias e aplicaçāo de ácido giberélico/ Marcel Bellato Spósito. -- Piracicaba, 1999. 67p.

Dissertação (mestrado) - - Escola Superior de Agricultura Luiz de Queiroz, 1999. Bibliografia.

1.Ảcido giberélico 2. Época de floração 3. Fisiologia vegetal 4. Limão - Taiti 5. Maturação 6. Regulador de crescimento vegetal 7. Vingamento

CDD 634.3 
Aos meus pais Pedro \& Ana,

Pelo amor, dedicação, ensinamentos e oportunidades

Ao meu irmão Kleber, pelo amor e companheirismo

\section{OFEREÇO}

\section{DEDICO}

A minha esposa Lygia, pela compreensão e todo amor que existe entre nós 
SUMÁRIO

Página

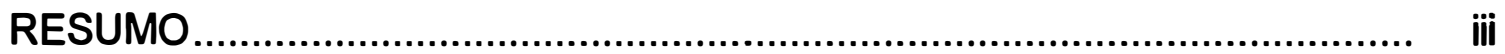

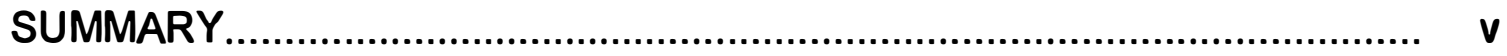

1 INTRODUÇÃO ............................................................................ 1

2 REVISÃO DE LITERATURA ........................................................... 4

3 PRIMEIRO TRABALHO CIENTÍFICO ................................................. 21

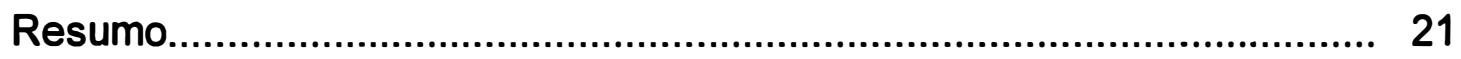

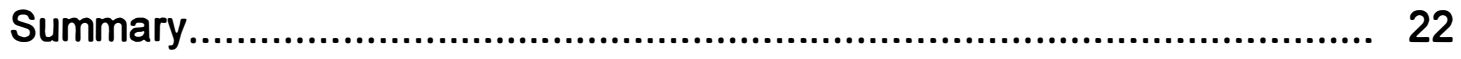

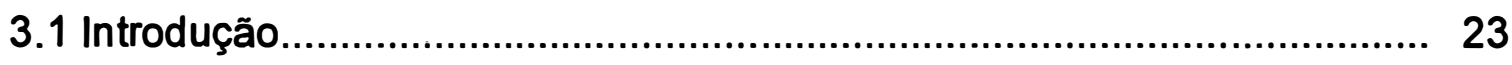

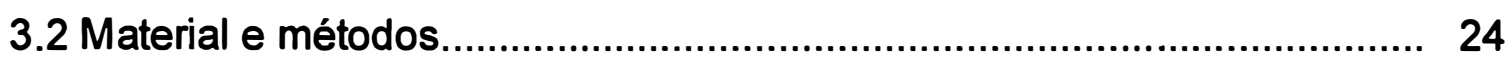

3.3 Resultados e discussão.............................................................. 26

3.4 Conclusões.................................................................................. 30

4 SEGUNDO TRABALHO CIENTÍFICO ............................................. 31

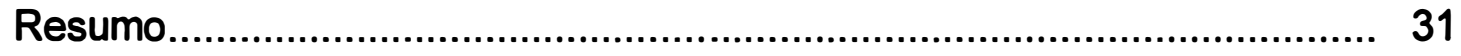

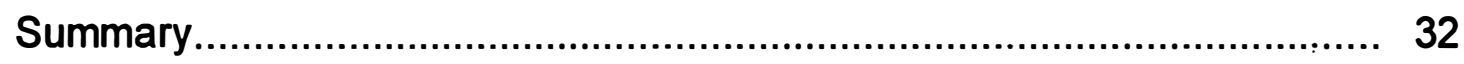

4.1 Introdução ................................................................................ 33

4.2 Material e métodos......................................................................... 34

4.3 Resultados e discussão...................................................................... 36

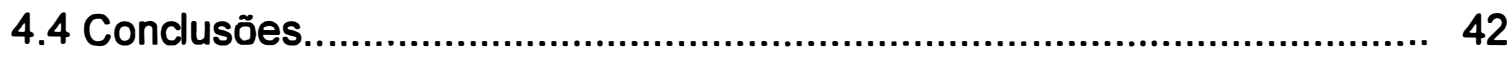

5 CONCLUSÕES GERAIS ............................................................ 43

REFERÊNCIAS BIBLIOGRÁFICAS................................................. 45

ANEXO 


\title{
FIXAÇÃO DE FRUTOS DE LIMEIRA ÁCIDA 'TAHITI', SUA RELAÇÃO COM O ACÚMULO DE GRAUS-DIAS E A APLICAÇÃO DE ÁCIDO GIBERÉLICO
}

\author{
Autor: Marcel Bellato Spósito \\ Orientador: Prof. Dr. Francisco de Assis Alves Mourão Filho
}

\section{RESUMO}

O presente trabalho foi conduzido em condições de campo, em pomar de limeiras ácidas 'Tahiti (Citrus latifolia Tanaka) com 8 anos de idade, enxertadas em limoeiros 'Cravo' (Citrus limonia L. Osbeck). Por ocasião da florada de maior intensidade (safra), ocorrida em outubro de 1997, avaliou-se a fixação dos frutos em relação aos diferentes quadrantes geográficos da copa. Por ocasião de florada de menor intensidade (entressafra), ocorrida em março de 1998, avaliou-se a fixação dos frutos em relação a aplicação de diferentes concentrações de ácido giberélico $\left(0,10,25,50\right.$ e $100 \mathrm{mg} \cdot \mathrm{L}^{-1}$ de $\left.\mathrm{GA}_{3}\right)$ na antese. Em ambos experimentos estimou-se 0 acúmulo de graus-dias necessários para a fixação e maturação dos frutos.

No primeiro experimento, observou-se que a fixação de frutos não foi influenciada pelos diferentes quadrantes geográficos da copa. A quantidade de graus-dias acumulados necessária para a fixação e maturação de frutos foi de 967,4 e 1338,4 , respectivamente. 
No segundo experimento, percebeu-se que a fixação de frutos foi influenciada pela aplicação de ácido giberélico $\left(G A_{3}\right)$, sendo que, a concentração de $10 \mathrm{mg} \cdot \mathrm{L}^{-1}$ de $\mathrm{GA}_{3}$ foi suficiente para incrementar a fixação, em relação a testemunha, em mais de 25 vezes $(12,72 \%$ e $0,46 \%$, respectivamente). A quantidade de graus-dias acumulados necessária para a fixação e maturação de frutos foi de 837,7 e 1115,2, respectivamente. 


\title{
FRUIT-SET OF 'TAHITI' LIMES, ITS RELATION OF THE DEGREE- DAYS AND THE GIBBERELLIC ACID APLICATION
}

\author{
Author: Marcel Bellato Spósito
}

Adviser: Prof. Dr. Francisco de Assis Alves Mourão Filho

\section{SUMMARY}

This work was conducted in field conditions in an eight-year-old acid 'Tahiti' lime trees (Citrus latifolia Tanaka), grafted on 'Rangpur' limes (Citrus limonia L. Osbeck). During high intensity flowering (harvest), occurring in October, 1997, fruit set was evaluated in relationship with different scion geographical quadrants. At less intense flowering (out-of-season), occurring in March, 1998, fruit set was evaluated in relationship with the application of different concentrations of gibberellic acid $\left(0,10,25,50\right.$ and $\left.100 \mathrm{mg} \cdot \mathrm{L}^{-1} \mathrm{GA}_{3}\right)$ during the anthesis. The accumulation of degree-days necessary for maturation and fruit set was evaluated in both experiments.

At the first experiment, the percentage of fruit set was similar in all scion geographical quadrants, and it was not influenced by the location of the branches in the canopy. The accumulated degree-days, after anthesis, of fruit set and fruit maturation were 967.4 and 1338.4 , respectively.

At the second experiment, $10 \mathrm{mg} \cdot \mathrm{L}^{-1}$ of gibberellic acid promoted more than $10 \%$ of fruit set, which represented an increase of more than 25 times in relation to the control. The accumulated degree-days, after anthesis, of fruit set and fruit maturation were 837.7 and 1115.2 , respectively. 


\section{INTRODUÇÃO}

Denomina-se citros o conjunto de plantas pertencentes aos gêneros Citrus, Poncirus e Fortunella, da família Rutaceae, cujos frutos de algumas espécies são muito apreciados. Seu cultivo estende-se pela maior parte das regiões tropicais e subtropicais, compreendidas entre os paralelos $44^{\circ} \mathrm{N}$ e $41^{\circ} \mathrm{S}$ (Agusti \& Almela, 1991).

Dentre as variedades citricas de interesse comercial, encontra-se a limeira ácida 'Tahiti' (Citrus latifolia, Tanaka), a qual, dentro do grupo de limas ácidas e limões, representa $68 \%$ do total de plantas cultivadas no Brasil (Figueiredo, 1991). A limeira ácida 'Tahiti', também é conhecida por 'Persian' e 'Bearss' em outras regiōes produtoras do mundo, tais como, Estados Unidos e México (Saunt, 1990).

Acredita-se que a limeira ácida 'Tahiti' seja um híbrido entre Citrus aurantifolia e Citrus medica sendo o centro de origem incerto, embora provavelmente, assim como outras limeiras, tenha se originado na Índia. 0 nome 'Tahiti' vem do fato dessa limeira ter sido introduzida nos Estados Unidos através do Taiti entre 1850 e 1880 (Barros, 1986; Saunt, 1990; Figueiredo, 1991).

Os maiores produtores mundiais dessa variedade são o México (540 mil toneladas) e o Brasil (535 mil toneladas), suprindo mais de $70 \%$ das necessidades mundiais do suco concentrado, bem como de óleos essenciais extraídos da casca (Carraro \& Cunha, 1994).

A área plantada no Brasil está estabilizada em aproximadamente 40.000 ha, apresentando produtividade média de 14 tha. A região Sudeste, no ano de 1991 , destacou-se como principal produtora, com $86 \%$ da produção nacional (480,2 mil toneladas), sendo o Estado de São Paulo responsável por $76 \%$ dessa produção (424 mil toneladas) (Carraro \& Cunha, 1994). A safra 1996/97 de lima ácida 'Tahiti', no Estado de São Paulo, atingiu 19,8 milhões de caixas, estimando-se uma receita de 113 milhões de reais, o que corresponde a $1,27 \%$ 
de toda atividade agropecuária desse Estado. Esse valor apresenta-se próximo a receita que acarreta as tangerinas $(1,29 \%)$, que engloba as variedades 'Poncã', 'Cravo' e 'Mexirica do Rio' além do tangor 'Murcote' (Donadelli et al., 1997).

Devido a precocidade na maturação de seus frutos, o período de colheita em limeira ácida 'Tahiti', no Brasil, ocorre normalmente entre os meses de dezembro e abril, época em que se produz $70 \%$ do volume anual. Esta sazonalidade e a inelasticidade da demanda no mercado, afetam o preço em sua comercialização (Coelho, 1993). Tal fato incentiva a busca de alternativas capazes de alterar a época de colheita, no intuito de induzir o amadurecimento dos frutos no período de baixa oferta, ou seja, na entressafra (Caetano et al.,1980; Silva, 1999).

Em regiões de clima seco, como o semi-árido dos estados do Nordeste brasileiro e em certas áreas do Estado de Minas Gerais, o florescimento em citros pode ser induzido através do uso adequado da irrigação. Um período de estresse hídrico seguido da retomada da irrigação, induz o florescimento, podendo, portanto, obter-se a colheita no período desejado (Silva, 1999). Entretanto, devido às dificuldades existentes em alterar a época de produção da limeira ácida 'Tahiti' no Estado de São Paulo, por decorrência das condições climáticas existentes, o aumento da produção no período de entressafra apresenta-se como solução mais viável (Stuchi \& Cy lo, 1998).

Portanto, a compreensão dos processos siológicos envolvendo a indução floral, a fixação dos frutos e do periodo necessário para que ocorra sua maturação, tornam-se imprescindíveis no manejo do pomar, no intuito de adequar a produção à época favorável de colheira.

Em várias regiões do mundo, onde há escassez de terras para o cultivo, técnicas modernas são utilizadas no aumento da produtividade e adequação da colheita a épocas de melhores preços. Entre elas a utilização de reguladores vegetais tem-se mostrado essencial para algumas variedades cítricas (Lange et al., 1982). 
$\mathrm{Na}$ Espanha, os reguladores vegetais autorizados pertencem aos grupos das giberelinas e auxinas, e são utilizados no aumento da produtividade e qualidade de frutos (Lopez, 1993). Na Califórnia (EUA), onde busca-se frutos de qualidade para a comercialização de fruta cítrica para mesa, $6 \%$ dos custos aplicados em pomares são relacionados a utilização de reguladores vegetais, valores semelhantes aos utilizados para o controle de plantas daninhas (Teófilo, 1998).

O uso racional dos reguladores vegetais pode permitir ao citricultor, eludir algumas das barreiras impostas pela genética e pelo ambiente, inibindo ou favorecendo uma maior fixação de frutos, assim como melhorando a qualidade dos frutos (Agustí \& Almela, 1991).

O presente trabalho visou avaliar a fixação de frutos de limeira ácida 'Tahiti' nos diferentes quadrantes geográficos da copa, no período de florada de maior intensidade (safra) e a utilização de ácido giberélico $\left(\mathrm{GA}_{3}\right)$ em aplicação exógena, em florada de menor intensidade (entressafra), relacionando o período compreendido entre a antese e a maturação dos frutos, nas duas épocas, às condições climáticas da região, através do acúmulo de graus-dias. 


\section{REVISÃO DE LITERATURA}

\subsection{Considerações gerais}

\subsubsection{Caracterização da variedade}

A limeira ácida 'Tahiti', apresenta porte médio a grande, com ramos curvados e poucos espinhos. A folhagem é verde densa, com folhas de tamanho médio, lanceoladas e com pecíolos alados. As flores, normalmente com cinco pétals, são de tamanho médio e não apresentam pólen viável (Coelho, 1993).

Por ser de constituição genética triplóide e esterilidade absoluta, seus frutos não apresentam sementes. Os frutos são de forma ovalada com peso médio de $70 \mathrm{~g}$; sua casca é de cor esverdeada, espessura fina e vesículas de óleo deprimidas. O suco representa cerca de $50 \%$ do peso do fruto, com teor médio de sólidos solúveis totais igual a $9{ }^{\circ}$ Brix, acidez titulável total de $6 \%$, "ratio" de 1,5 e o teor de ácido ascórbico entre 20 e $40 \mathrm{mg} / 100 \mathrm{ml}$ de suco (Figueiredo, 1991).

Entre os clones de limeira ácida 'Tahiti' existentes, dois são os mais utilizados na citricultura brasileira: O clone IAC-5 e o clone "quebra-galho". 0 clone IAC-5 apresenta alta produtividade, maior tolerância ao vírus da tristeza e não apresenta hipertrofia do cálice de flores, ocorrendo maior volume de produção no primeiro semestre, período em que os preços são mais baixos, devido a grande oferta de frutos (Donadio et al., 1995). 


\subsubsection{Reguladores vegetais}

A totipotência das células vegetais é uma evidência de que todos os genes presentes no zigoto estão também presentes em cada célula viva de uma planta adulta. Entretanto, em qualquer célula somente genes selecionados são expressos e transcritos em RNAm e subsequentemente traduzidos em proteinas especificas que determinam a identidade da célula (Raven et al., 1996).

Biologistas moleculares de plantas vêm estudando inúmeros genes que são ativados ou reprimidos por fatores como a luz, estresse ambiental e hormônios (Raven et al., 1996).

Os hormônios vegetais são substâncias orgânicas que desempenham uma importante função na regulação do crescimento. Os hormônios são sintetizados em certos sítios da planta podendo atuar no próprio tecido onde foi sintetizado ou ser translocados para outros tecidos onde produzem respostas fisiológicas especificas. A palavra "hormônio" vem do termo grego horman, que significa "excitar". Entretanto, está claro que alguns hormônios têm influência inibitória. $\mathrm{O}$ termo regulador vegetal parece ser o mais correto. Porém, esse termo necessita de qualificação, porque a resposta a um regulador específico depende não somente de sua estrutura química, mas também de como ele é "percebido" pelo tecido alvo, ou seja, o mesmo hormônio pode desencadear diferentes respostas em tecidos diferentes ou em épocas distintas do desenvolvimento de um mesmo tecido (Raven et al., 1996).

Os hormônios vegetais podem ser reconhecidos pelas células através de sua interação com proteínas específicas chamadas de receptores. Cada proteina receptora contem um sítio de ligação específico para um hormônio particular. A ligação de um hormônio com o seu receptor ativa uma via de resposta particular na célula (Raven et al., 1996).

Os cinco grupos de hormônios geralmente reconhecidos são: as auxinas, as citocininas, o etileno, o ácido abscísico e as giberelinas (Raven et al., 1996). 
A forma de translocação dos hormônios vegetais varia dependendo da substância. $O$ transporte das giberelinas ocorre via parênquima, podendo também ser transportadas via floema, e via xilema como glicosídeos (Agustí \& Almela, 1991).

Os fatores responsáveis pelo processo de crescimento dos órgãos de uma planta podem ser separados em quatro grupos, sendo seus limites não muito precisos. São eles: nutricionais, relacionados a todos os nutrientes necessários para as sínteses dos constituintes celulares; hormonais, que através de seus "mensageiros químicos", controlam a natureza e intensidade desse processo; genéticos, herdados de organismos antecessores e que podem marcar de um modo decisivo a natureza e amplitude de sua conduta frente aos fatores nutricionais e hormonais; e ambientais, que influenciam pelas condições do meio, podendo modificar quantitativamente, inibindo ou provocando esse crescimento (Agustí \& Almela, 1991).

Prioritariamente, os fatores nutricionais estão relacionados com a disponibilidade de carboidratos, e os hormonais são os que determinam a capacidade de dreno do fruto por carboidratos (Agustí, 1999). As práticas culturais têm por finalidade aplicar os conhecimentos sobre o desenvolvimento das plantas para lograr uma melhor produção e qualidade de frutos (Agustí, 1999).

Em citricultura, os objetivos do emprego de reguladores vegetais são diversos e podem ser aplicados em diferentes estádios fisiológicos da planta e dos frutos. Os principais objetivos são: o aumento da fixação de frutos, o aumento do tamanho dos frutos, o controle da queda pré-colheita, a conservação dos frutos na planta, o desbaste químico, etc (El-Otmani, 1992).

A importância da síntese e a ação de hormônios como as giberelinas e auxinas no desenvolvimento de frutos vem sendo estudada. Em citros, as auxinas não aparecem como fator limitante no desenvolvimento dos frutos jovens, evidenciando a essencial presença das giberelinas neste processo (Talón et al., 1990; Krajewski \& Rabe, 1995). 


\subsection{Florescimento em citros}

Vários mecanismos são propostos para explicar o florescimento em plantas cítricas. Lovatt et al. (1988) atribuem a indução floral em citros a um período de repouso associado a baixas temperaturas invernais ou a um estresse hídrico prolongado, tendo como conseqüência uma inibição temporal do crescimento dos ramos.

A indução floral, que pode ser definida como o evento inicial do processo que leva a planta a capacidade de florescer, através da transcrição e expressão dos genes (Davenport, 1990), tem seu início, portanto, com a paralisação do crescimento vegetativo (Davies \& Albrigo, 1994).

Temperaturas abaixo de $12,5^{\circ} \mathrm{C}$, levam à paralisação do crescimento de ramos e diminui o crescimento radicular em plantas cítricas. Entretanto, algumas semanas com temperaturas abaixo de $25^{\circ} \mathrm{C}$ induzem o florescimento em significativa quantidade. Durante esse período, gemas vegetativas desenvolvem a capacidade de florescer (Davies \& Albrigo, 1994).

Em áreas tropicais e subtropicais, com exceção dos microclimas, as temperaturas observadas favorecem uma constante atividade vegetativa (Davies \& Albrigo, 1994). Porém, baixos suprimentos de água nessas regiōes, no máximo de $100-150 \mathrm{~mm}$ de precipitação por mês, apresentam o mesmo efeito que as baixas temperaturas em área subtropical, ou seja, após determinado período de estresse, ocorre indução do florescimento (Cassin et al., 1969).

Na Itália, para a obtenção de colheita de limão 'Verdelli', na entressafra, submete-se as plantas a um adequado nível de estresse hídrico. Esse método também é utilizado em limoeiros em Israel, Espanha e em limeira ácida 'Tahiti' na Flórida (EUA) (Davenport, 1990). Geralmente a intensidade da floração está relacionada com o nivel e duração desse estresse (Southwick \& Davenport, 1986; Barbera \& Carimi, 1988; Lovatt et al.,1988). Um estresse muito severo, pode induzir uma desordem fisiológica na planta promovendo uma grande 
queda de flores e frutos. Em limoeiro 'Femminello', a melhor resposta foi obtida quando o potencial hídrico foliar não excedeu a -2,7 Mpa (Barbera \& Carimi, 1988).

A limeira ácida 'Tahiti' necessita de aproximadamente 4 a 5 semanas de efetivo estresse hídrico, apresentando um potencial hídrico nas folhas observadas ao meio-dia de -2,8 a -3,5 Mpa para induzir o florescimento, o qual ocorre, aproximadamente, entre 20 a 28 dias após o reinicio da irrigação (Cassin et al., 1969; Southwick \& Davenport, 1986; Babera \& Carimi, 1988).

Nir et al. (1972), avaliando gemas de limoeiro 'Eureka' (Citrus limon (L.) Burm. f.), com 12 anos de idade, observaram que a diferenciação da gema em floral ocorre durante o período de estresse hídrico, portanto antes da retomada da irrigação.

O padrão de crescimento entre ramos e raízes, sem a ocorrência dessa paralisação (decorrente de algum tipo de estresse), apresenta-se cíclico, estando associado a um elevado nível de translocação de hormônios (Bower et al., 1990).

Talón et al. (1997) sugeriram que as baixas temperaturas, diminuem o nivel endógeno de giberelinas em citros, no período próximo a diferenciação. A inibição da mitose das gemas como resultado de um fator de estresse, pode ser seguido por uma rápida divisão celular que conduza a formação de flores, presumivelmente pela ausência de giberelinas (Bernier et al., 1970). Portanto, a diminuição do conteúdo endógeno de giberelinas, está diretamente relacionado com a diferenciação das gemas em florais (Talón et al., 1997). Esse comportamento pode ser modificado através de aplicações exógenas de ácido giberélico. $\mathrm{O}$ ácido giberélico mostrou-se inúmeras vezes como um potente inibidor de florescimento em citros (Moss, 1970; Nir et al., 1972; Lenz \& Karnatz, 1975; Guardiola et al, 1982), sendo observado que a limeira ácida 'Tahiti' responde efetivamente, assim como outras espécies cítricas (Davenport, 1983). A aplicação desse regulador vegetal antes do estádio de diferenciação das gemas em florais (período de estresse), inibe essa diferenciação. 
Entretanto, quando aplicado após o aparecimento dos primórdios das sépalas, estádio em que as gemas já estão diferenciadas em florais, essas não se desdiferenciam, ou seja, não voltam a ser gemas vegetativas, formando-se, portanto, gemas florais e consequentemente flores (Davies \& Albrigo, 1994).

Davenport (1983) observou que o suprimento continuado de ácido giberélico exógeno, inibiu o florescimento, nos ramos tratados de limeira ácida 'Tahiti', em aproximadamente um ano, entretanto, nenhum aumento do crescimento vegetativo durante ou após esse tratamento ou em relação ao florescimento após o término das aplicações foi notado. O potencial de produzir flores não se acumula durante o período de inibição (Davenport, 1983). A aplicação exógena de ácido giberélico, não altera a morfologia das brotações, como um possivel alongamento dos internódios, tamanho das folhas (Moss, 1970).

Em relação aos tipos de inflorescências que ocorrem em plantas citricas, Guardiola et al. (1977) classificaram as brotações de acordo com o número de folhas e flores em: brotos generativos uniflorais (com uma única flor e sem a presença de folhas), brotos generativos multiflorais (várias flores e sem a presença de folhas), brotos mistos uniflorais (com uma única flor e a presença de várias folhas) e brotos mistos multiflorais (com várias flores e a presença de várias folhas).

\subsection{Fixação do fruto cítrico}

As variedades cítricas de importância comercial florescem profusamente produzindo ao redor de $10^{4}$ a $2,5 \times 10^{5}$ flores, por planta em produção, porém a queda de flores, devido a fatores ambientais e fisiológicos é tão elevada que o número de frutos colhidos não superam $10 \%$ das flores formadas, alcançando normalmente valores entre 0,1 e 3,5\% (Agustí et al., 1982; Monselise, 1986). Isto ocorre principalmente como resultado da competição dos frutos em 
desenvolvimento por fotoassimilados e minerais, sendo um processo intimamente regulado pelo balanço hormonal da planta (Powell \& Krezdorn, 1977).

A maioria das variedades cítricas requer um desenvolvimento de sementes para a frutificação. Este processo depende da polinização, crescimento do tubo polínico e da fertilização (El-Otmani, 1992; Guardiola, 1992). A polinização tem papel fundamental na fixação, pois aumenta os niveis endógenos de giberelinas, os quais aumentam a força de dreno de fotoassimilados e minerais, reduzindo assim a abscisão de ovário (Talón et al., 1997; Bem-Cheikh et al., 1997). Em variedades que apresentam sementes, a fixação ocorre com facilidade e, às vezes, em excesso, podendo desencadear alternância na produção (Spósito et al., 1998). A maior parte dos hormônios relacionados com a fixação de frutos encontram-se nos tecidos de sementes (Agustí, 1999).

Em variedades partenocárpicas, o estímulo é atribuído às paredes do ovário, onde ocorre a síntese de receptores dos fatores que regulam a fixação dos frutos (Monselise, 1977). Talón et al. (1990) observaram que em variedades com capacidades similares de fixação de frutos, sendo essas partenocárpicas ou com sementes, apresentaram conteúdos semelhantes de giberelinas, indicando, portanto, esse hormônio como o responsável pela fixação. conteúdo de giberelinas em ovários em desenvolvimento, de variedades partenorcárpicas, é fator limitante na fixação e desenvolvimento dos frutos (Talón et al., 1992).

Wiltbank \& Krezdorn (1969), estudando as giberelinas endógenas em variedades de laranjeira doce do tipo Navel (umbigo), as quais não apresentam sementes, observaram que no período de queda de pétalas, ocorreu uma diminuição, de aproximadamente um terço da concentração de giberelinas existentes em ovários, quando comparado com o período de antese. Entretanto, uma semana após essa queda, ocorreu um incremento na concentração desse hormônio, mantendo valores constantes por um periodo de nove semanas. Os 
autores observaram uma correlação positiva entre a concentração de ácido giberélico e o desenvolvimento do fruto em seus primeiros estádios.

Embora a ausência de sementes seja uma característica comercial desejável, principalmente para o comércio de fruta fresca, as variedades sem sementes produzem menos que as variedades com sementes. Algumas dessas variedades, também, são muito sensiveis ao estresse nutricional e ambiental, o que pode causar uma queda acentuada de frutos em desenvolvimento o que resulta em baixa produção. Quando bem manejadas, essas variedades apresentam boa produção e com regularidade (Guardiola, 1992).

Os frutos cítricos apresentam em seu desenvolvimento uma típica curva sigmoidal, dividida em três fases. A primeira fase, é o estádio em que ocorre a divisão celular, período compreendido entre a antese e a queda fisiológica de frutos. Nessa fase é quando ocorre a maior intensidade de abscisão floral e de ovários, fixando na maioria das vezes menos de $1 \%$ do número total de flores formadas. A possibilidade de um fruto se fixar ou cair ocorre durante esta fase. O final do período de abscisão coincide com a transição metabólica entre a divisão celular e o alargamento celular. A segunda fase, é o estádio caracterizado por um crescimento rápido do fruto devido ao alargamento das células (de 4 a 8 meses, dependendo da variedade). A terceira fase é compreendida pelo estádio de maturação do fruto (Talón et al., 1997).

O primeiro período de abscisão em frutos ocorre nos estádios iniciais de desenvolvimento, estendendo-se desde a queda de pétalas até, aproximadamente, 3 a 4 semanas após a antese. Entretanto, existe um segundo período de abscisão, dependendo da variedade, com menor expressão, que ocorre entre novembro e dezembro, no hemisfério Sul (Davies \& Albrigo, 1994). Após esses dois períodos há uma drástica diminuição da abscisão até a maturação do fruto, excetuando-se sobre condições ambientais adversas.

A queda fisiológica é uma disfunção causada, provavelmente, pela competição dos frutos em desenvolvimento por carboidratos, água e outros 
metabólitos, apresentando-se mais severa quando a temperatura nas folhas aproxima-se de $35-40^{\circ} \mathrm{C}$ ou em período de estresse hídrico. A maior competição ocorre quando os frutos possuem um diâmetro entre 0,5 a 2,0 cm (Davies \& Albrigo, 1994).

O controle da fixação e abscisão de frutos cítricos é um fenômeno complexo, regulado pelas condições do ambiente, controle genético e regulação metabólita, ocorrendo através de um sinal hormonal (Talón et al., 1997).

Os hormônios vegetais controlam a fixação de frutos, provavelmente pela habilidade em mobilizar fotoassimilados e minerais (Monselise \& Goldschmidt, 1982). Segundo Moss (1976), a fixação de frutos cítricos está relacionada com a competitividade entre os frutos por fotoassimilados. Até os frutos atingirem cerca de 4,0 cm de diâmetro, estão passíveis de caírem, caso não seja mantida uma taxa mínima de crescimento ou se o mecanismo de abscisão for estimulado artificialmente através do aumento do nível de etileno endógeno (Moss, 1976). Quando há uma deficiência de suprimento, um sinal hormonal é gerado, iniciando um mecanismo de proteção da planta, como por exemplo, paralisação do desenvolvimento, fechamento de estômatos, ou abscisão de órgãos (Talón et al., 1997).

O processo de abscisão de frutos é precedido por determinadas mudanças estruturais que ocorrem após a formação de uma camada de separação na base do pedúnculo, chamada zona de abscisão (Raven et al., 1996). As enzimas quebram as paredes celulares na camada de separação. As mudanças na parede celular podem incluir enfraquecimento da lamela média e hidrólise das próprias paredes celulósicas. Abaixo da camada de separação, uma camada protetora composta de células fortemente suberificadas é formada, isolando posteriormente o ponto de abscisão, antes que fruto desprenda-se (Raven et al., 1996). Aparentemente o ácido abscísico (ABA) e o etileno ativam a abscisão (Talon et al., 1997). O nível endógeno de ABA apresenta-se alto em ovários em desenvolvimento tanto no período de queda de pétalas (8 a 12 dias após a antese), como no período de queda fisiológica 
("June drop", no hemisfério Norte), coincidindo com os dois picos de abscisão (Talón et al., 1990). Os níveis endógenos de ABA também aumentam durante períodos de estresse. Entretanto, a aplicação exógena de $A B A$ não causa abscisão (Goren, 1993).

A abscisão dos frutos jovens tende a ocorrer na zona do pedúnculo, denominada zona $A$, diferentemente da abscisão de frutos maduros, que normalmente ocorrem na zona do cálice, denominada zona C (Figura 1) (Monselise, 1986; Huberman et al., 1988).

Figura 1. Zonas de abscisão de frutos. A zona A está localizada entre o ramo e o pedúnculo e a zona $C$ entre o cálice e o fruto (Huberman et al.,1988).

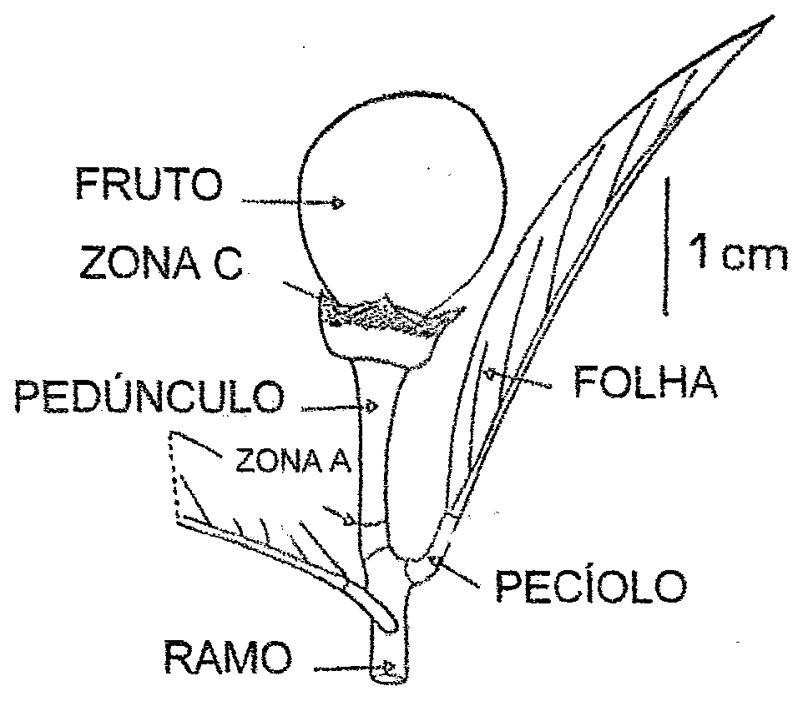

A abscisão de frutos cítricos é induzida por uma seqüência hormonal, ocorrendo: Incremento de ácido abscísico $\rightarrow$ incremento do ácido 1aminociclopropano-1-carboxílico (ACC) $\rightarrow$ liberação de etileno $\rightarrow$ abscisão de frutos (Talón et al., 1997). Observa-se uma redução de ácido giberélico no período de antese, principalmente em variedades auto-incompativeis, como é o caso de tangerineiras 'Clementinas', e em ovários não polinizados de 
variedades que apresentam sementes. Nesse período ocorre um incremento de ácido abscísico. $O$ ácido abscísico através da síntese do ACC, aumenta os niveis endógenos de etileno, o qual concentra-se nas zonas de abscisão. Em variedades que possuem um nível de abscisão baixo, normalmente os niveis de ácido giberélico aumentam na antese e os niveis de ácido abscísico apresentam-se baixo. A aplicação exógena de ácido giberélico $\left(\mathrm{GA}_{3}\right)$ em variedades auto-incompativeis, supre completamente $\mathrm{o}$ incremento do ácido abscísico e reduz a abscisão de frutos pós-antese (Talón et al., 1997).

Em relação às inflorescências, as brotações que apresentam folhas, ou seja, os brotos mistos, possuem uma maior capacidade de fixação dos frutos formados, entre 4 e 6 vezes maior que as inflorescências sem folhas, os brotos generativos (Sauer, 1951; Lenz, 1966). A contribuição das folhas à fixação está relacionada a fatores hormonais e nutricionais (Monselise et al., 1981). Em inflorescências de brotações mistas, há uma maior concentração de giberelinas e citocininas quando comparadas com inflorescências generativas (Saidha et al., 1985).

Moss et al. (1972), utilizando como parâme ?ros a relação fonte-dreno de carboidratos entre 0 potencial das folhas ac acentes e a demanda no desenvolvimento de frutos, observaram que as inflorescências com folhas possuem suficiente superfície foliar e capac acs fotossintética para assegurar o desenvolvimento dos frutos. Nesse experimento, observou-se folhas jovens em que foram utilizados carbono marcado $\left({ }^{14} \mathrm{C}\right)$, ocorrendo a distribuição de reservas de carboidratos, sem que ocorresse competição pelos frutos adjacentes. Entretanto, os frutos situados em inflorescências sem folhas, tiveram que obter todo fotoassimilado necessário para seu desenvolvimento de folhas velhas, cuja capacidade fotossintética mostrou-se três vezes menor do que as folhas jovens.

A importância das folhas nesse processo baseia-se na capacidade de sintetizar e exportar metabólitos aos frutos em desenvolvimento, explicando a persistência na planta, dos frutos situados próximos às folhas (Zucconi et al., 
1978). Um déficit de fotoassimilados durante 0 estádio inicial de desenvolvimento do fruto provoca sua abscisão (Erner \& Bravdo, 1983).

Erickson (1968) demostrou que são necessários $2,3 \mathrm{~m}^{2}$ de folhas para se produzir $1,0 \mathrm{Kg}$ de frutos, em plantas cítricas com nove anos de idade. Iwahori (1978) sugeriu que são necessárias 25 folhas para nutrir um fruto cítrico.

\section{4 Ácido giberélico na fixação dos frutos cítricos.}

As giberelinas estão relacionadas com o desenvolvimento e a manutenção do estado juvenil nos vegetais, através dos processos de estímulo à germinação, indução de síntese de enzimas, alongamento, retardo da degradação de clorofila, dentre outros (Barceló et al., 1992).

Até o momento foram identificadas 89 diferentes giberelinas, sendo 12 apenas presentes no fungo Gibberella fujikuroi, 64 em plantas superiores e 13 presentes em ambos (Sponsel, 1995). As giberelinas (GAs) são ácidos diterpenóides tetracíclico, biosintetizado a partir do ácido mevalônico. Há evidências da existência, em frutos em desenvolvimento e em sementes, de enzimas que convertem o ácido mevalônico em giberelinas (Graebe, 1987).

A primeira substância promotora de crescimento não indólica, isolada em citros, foi a giberelina $A_{1}\left(G A_{1}\right)$, extraída da tangerina 'Satsuma' (Citrus unshiu Marc.) (Kawarada \& Sumiki, $1959^{1}$, citados por El-Otmani et al., 1995). Foram isoladas 20 diferentes $G A s$, incluindo $G_{(1,3,4,5,7,8,9,14,17,19,20,24,25,29,44)}$, em diferentes espécies e tecidos de citros (El-Otmani et al., 1995).

Das 89 giberelinas encontradas nas plantas superiores e no fungo Gibberella fujikuroi, apenas dois produtos comerciais estão disponiveis no

\footnotetext{
' KAWARADA, A.; SUMIKI, Y.; The ocurrence of gibberellin $A_{1}$ in water sprouts of citrus. Bull. Agric. Chem. Soc. Jpn., v.23, p.343-344, 1959.
} 
mercado: o ácido giberélico $\left(G_{3}\right)$ e uma mistura de $G_{4}$ e $G A_{7}$, ambos produzidos pela fermentação do fungo Gibberella fujikuroi (Gianfagna, 1995).

A aplicação de reguladores vegetais para aumentar a fixação de frutos cítricos vem sendo estudada em muitas variedades, todavia a resposta não apresenta uniformidade, dependendo do tipo de substância aplicada, concentração e da variedade cítrica utilizada. A aplicação exógena de ácido giberélico $\left(\mathrm{GA}_{3}\right)$ tem mostrado bons resultados, principalmente em tangerineiras e em seus híbridos (Agustí \& Almela, 1991; Castro, 1998).

De acordo com o momento em que a aplicação de ácido giberélico é efetuada, pode-se regular o florescimento através de sua inibição, aumentar a fixação ou promover um maior período de maturação dos frutos (Agustí \& Almela, 1991).

A diversidade de respostas, é decorrente da interação do ácido giberélico com outros hormônios vegetais, dependendo do momento e concentração com que esse ácido é aplicado (López, 1993). A fixação de frutos ocorre, basicamente, em variedades que apresentam baixas concentrações dé giberelinas (Talón et al., 1992).

Estudos utilizando ${ }^{14} \mathrm{C}$ mostraram que, com a aplicação de ácido giberélico, ocorreu um aumento da força de dreno dos frutos por fotoassimilados, aumentando a relação fruto fixado/flor, em função da concentração utilizada e época de aplicação (Monselise \& Goldschmidt, 1982).

O momento em que deve ser efetuada a aplicação do ácido giberélico é relativamente curto e em muitos casos não está claramente relacionado com uma mudança fenológica no desenvolvimento da planta. Para a máxima resposta à fixação dos frutos cítricos, a aplicação deve ser ministrada no período de florescimento, compreendido entre a antese e a queda de pétalas (García-Martínez \& García-Papi, 1979a; García Luis, 1987; Castro, 1998). O florescimento é definido por Bellows \& Morse (1986), como sendo o período compreendido entre $10 \%$ das flores abertas (antese) até $75 \%$ das flores maduras perderem suas pétalas, formando frutos. 
Aplicações de ácido giberélico em folhas e frutos de tangerineira 'Clementina Fino', incrementaram o conteúdo de N, P e K dos frutos em desenvolvimento, ao mesmo tempo em que reduziram o conteúdo desses minerais em folhas adjacentes (Garcia-Martínez \& García-Papi, 1979b).

Resultados similares foram obtidos por Krezdorn \& Brown (1970), aplicando em tangelo 'Robinson', na Flórida (EUA), concentrações de 10, 15 e $25 \mathrm{mg} . \mathrm{L}^{-1}$ de ácido giberélico; Krezdorn \& Jernberg (1977), com as variedades 'Orlando', 'Minneola', 'Nova' e 'Robinson', com concentrações de $\mathrm{GA}_{3}$ entre 10 e $75 \mathrm{mg} . \mathrm{L}^{-1}$ e Tominaga (1997) em tangerineira 'Poncã', aplicando $200 \mathrm{mg} / \mathrm{L}$ de $\mathrm{GA}_{3}$, no período de antese. Entretanto, Duarte \& Guardiola (1996), aplicando 10 $\mathrm{mg} \cdot \mathrm{L}^{-1}$, em tangerineira 'Fortune', na época da antese, em meados de maio na Espanha, observaram que ocorreu uma redução da abscisão de frutos entre o final de maio e o início de junho, sendo que esse efeito mostrou-se passageiro. Ocorreu um incremento da abscisão no final de junho, chegando a valores semelhantes ao da testemunha.

Na Flórida (EUA), recomenda-se a aplicação de ácido giberélico, sem a adição de surfactantes, no período de antese para o incremento da fixação de frutos em tangelos (Davies et al., 1998).

$\mathrm{Na}$ África do Sul, a aplicação de $10 \mathrm{mg} \cdot \mathrm{L}^{-1}$ de ácido giberélico é recomendada em todos os talhões em produção da tangerineira 'Clementina', na fase de floração (Lange et al., 1982). Na Espanha a utilização de $\mathrm{GA}_{3} \mathrm{em}$ tangerineira 'Clementina' é bem difundida, utilizando-se concentrações entre 5 a $15 \mathrm{mg} \cdot \mathrm{L}^{-1}$ (Agustí \& Almela, 1991). Esta prática advém do fato que nessa variedade $o$ incremento na fixação dos frutos não reduz o tamanho dos mesmos (Damigella et al., 1970; Cuñat et al., 1974), o que normalmente ocorre com outras variedades de tangerineiras e seus híbridos (Brosh \& Monselise, 1977).

Concentrações entre 10 e $20 \mathrm{mg} \cdot \mathrm{L}^{-1}$ de $\mathrm{GA}_{3}$ são mais utilizadas, porém as respostas a estas aplicações não apresentaram uniformidade e dependem da variedade, sendo que em geral as tangerineiras, com exceção da 'Satsuma', àquelas que melhor responderam a essa aplicação (Castro, 1998) 
García-Martínez \& García-Papí (1979a), observaram com o aumento do número total de frutos fixados por planta, um decréscimo no peso dos frutos, apresentando uma relação linear quando comparados com os valores logarítmicos da concentração de ácido giberélico entre 5 e $200 \mathrm{mg} \cdot \mathrm{L}^{-1}$.

O efeito da aplicação do ácido giberélico está diretamente relacionado a produtividade das parcelas. A aplicação de ácido giberélico tem melhores resultados em pomares de baixa produtividade (Guardiola, et al.1977; Ragone, 1992).

\subsection{Associação de graus-dias acumulados e desenvolvimento do fruto.}

O período necessário para que ocorra a maturação dos frutos cítricos está fortemente influenciado pelos elementos do clima (Cassin et al., 1969). Em experimentos com laranjeira 'Valência', observou-se que em regiões de clima tropical o desenvolvimento de frutos ocorre em menor período de tempo. A colheita ocorre no máximo um mês após alcançada a maturação. Em regiões de clima subtropical, esse período pode ampliar-se em até cinco meses. Em clima temperado, os frutos podem manter-se, nas plantas, por até três meses (Reuther, 1973).

O estudo das interações entre as condições ambientais e o desenvolvimento das plantas, é de fundamental importância, do ponto de vista técnico e estratégico, haja vista que a produção e qualidade dos frutos cítricos são afetadas sobremaneira pelo clima (Di Giorgi et al., 1991).

A maioria dos pomares comerciais do Estado de São Paulo, encontramse entre as latitudes de 20 e $23^{\circ} \mathrm{S}$, em altitude média de $600 \mathrm{~m}$, com clima predominante Cwa, seguido pelo clima $A w$, ambos relativamente secos no inverno (Volpe, 1992). Nessas condiçōes, podem ocorrer várias floradas de diferentes intensidades por safra, ocorrendo estes surtos de florescimento, normalmente após um período de déficit hídrico (Ortolani et al., 1991). 
A relação existente entre 0 desenvolvimento dos frutos cítricos e 0 acúmulo de graus-dias (GD), tem sido estudada em diferentes variedades (Reuther, 1973; Kimball, 1984; Bellows \& Morse, 1986; Ortolani et al., 1991; Volpe, 1992).

A conceito de graus-dias considera uma temperatura como "zero vegetativo", na qual a planta paralisa sua atividade ou reduz sua taxa de crescimento a valores mínimos. Esse índice é chamado de temperatura basal (Tb). Para os citros a temperatura basal é de 12,8 a $13^{\circ} \mathrm{C}$ (Ortolani et al., 1991; Volpe, 1992).

E importante salientar que, além da temperatura basal, deve-se considerar, também, a temperatura máxima na utilização do método de grausdias. Para citros utiliza-se como temperatura máxima $35^{\circ} \mathrm{C}$. Acima desta temperatura, normalmente, ocorre a paralisação ou diminuição das atividades biológicas da planta (Volpe, 1992).

Para o acúmulo de graus-dias, um dos métodos utilizados é o descrito por Volpe (1992), através da utilização da fórmula:

$$
G D=\left[\left(T_{\max }+T_{\min }\right) / 2\right]-T b
$$

Sendo, GD: graus-dias; $T_{\max }$ : temperatura máxima; $T_{\min }$ : temperatura mínima; Tb: temperatura basal $\left(13^{\circ} \mathrm{C}\right.$, para citros).

Esse método considera que uma planta necessita de uma certa quantidade de energia equivalente à soma de graus térmicos acima da temperatura basal, para completar determinadas fases fenológicas ou o ciclo total (Ortolani et al., 1991).

Os graus-dias acumulados têm sido utilizados para estimar a quantidade de calor exigida para a maturação dos frutos citros. Para isto utiliza-se o período compreendido entre o florescimento e a maturação dos frutos, relacionando esse último com o "ratio" desejado para cada variedade (Lomas et 
al., 1970; Kimball, 1984; Volpe, 1992). Com isso pode-se determinar, aproximadamente, a época em que ocorrerá a maturação e a colheita, para cada variedade (Volpe, 1992).

Com base em informações obtidas por Ortolani et al. (1991), para laranjeiras doces, verificou-se que a maturação de frutos de variedades precoces ocorre com $2500 \mathrm{GD}$, as de meia estação com $3100 \mathrm{GD}$ e as tardias com 3600 GD.

Sam et al. (1988) ${ }^{2}$ citados por Sentelhas et al. (1997), obtiveram para a limeira ácida 'Tahiti', entre o período de florescimento e de maturação, um valor aproximado de $1220 \mathrm{GD}$, utilizando como temperatura basal $13^{\circ} \mathrm{C}$.

A utilização da estimativa da duração do período entre o florescimento e a maturação, através de técnicas agrometeorológicas, tem sido utilizada no Estado de São Paulo para a determinação de zonas climáticas de maturação de diversas fruteiras, como abacateiro, laranjeira e videira (Sentelhas et al., 1996), apresentando resultados satisfatórios e importantes no planejamento do manejo dessas culturas (Sentelhas et al., 1997).

2 SAM, O.; ROSADO, F.; GONZALES, M. E. Crescimento e desarollo de frutos de lima Persa (Citrus latifolia Tanaka) durante dos años en las condiciones del sureste de la habana. Revista do Centro Agricola, Las Villas, v. 15, n.2, p.6271, 1988. 


\section{PRIMEIRO TRABALHO CIENTÍFICO}

\section{FIXAÇÃO DE FRUTOS DE LIMEIRA ÁCIDA 'TAHITI' EM RELAÇÃO AOS QUADRANTES GEOGRÁFICOS DA COPA E AO ACÚMULO DE GRAUS-DIAS}

MARCEL BELLATO SPÓSITO 3 ; FRANCISCO DE ASSIS ALVES MOURĀO FILHO4; PAULO SÉRGIO RODRIGUES DE ARAÚJO5

\section{Resumo}

Avaliou-se a porcentagem de fixação de frutos de limeiras ácidas 'Tahiti', com sete anos de idade, enxertadas em limoeiro 'Cravo', cultivadas no espaçamento de 8,0 x 5,0 metros, em relação aos diferentes quadrantes geográficos da copa e ao acúmulo de graus-dias para a fixação e maturação de frutos, nas condições de Piracicaba-SP. Adotou-se 0 delineamento experimental em blocos casualizados, sendo determinada a porcentagem de fixação de frutos nos diferentes quadrantes geográficos da copa, através de

\footnotetext{
3 Pesquisador cientifico do Fundecitrus; Pós-graduando do Depto. de Produção VegetalESALQ/USP, bolsista Capes.

${ }^{4}$ Prof. Dr. Depto. de Produção Vegetal, C. P. 09, CEP 13418-900, Piracicaba-SP. Autor correspondente. Email: famourao@esalq.usp.br. Bolsista CNPq.

${ }^{5}$ Pós-graduando do Depto. de Produção Vegetal-ESALQ/USP.
} 
contagem semanal do número de flores e frutos, em cada ramo previamente marcado, desde a antese até a maturação dos frutos. Os dados obtidos foram submetidos à analise de variância e as médias de porcentagem de frutos fixados comparadas através do teste de Tukey a 0,05 de probabilidade. Para avaliar a quantidade de graus-dias acumulados utilizou-se a análise de regressão. Observou-se que a porcentagem de frutos fixados apresentou comportamento similar, independentemente dos quadrantes geográficos, não sendo influenciada pela localização dos ramos na copa. A partir da antese, para a estabilização da fixação e maturação de frutos, foram necessários 967,4 e 1338,4 graus-dias acumulados, respectivamente.

Palavras chave: Citrus latifolia, frutificação, maturação, pegamento.

\section{Summary}

\section{FRUIT SET OF 'TAHITI' LIMES AT FOUR SCION QUADRANTS AND ITS RELATIONSHIP WITH THE ACCUMULATION OF DEGREE-DAYS}

The percentage of fruit set in 'Tahiti' limes budded on 'Rangpur' lime at four scion quadrants and its relationship with the accumulation of degree-days for fruit set and fruit development were studied at Piracicaba, state of São Paulo, Brazil. The trees were seven years old cultivated at 8,0 $\times$ 5,0 meters. The statistical design consisted of randomized blocks. Data collected included the percentage of fruit set in different canopy geographical quadrants, through weekly counts of the number of flowers and fruits, in each branch previously marked, from the anthesis to fruit maturation. The collected data were submitted 
to the analysis of variance and the averages of percentage of fastened fruits compared through the test of Tukey at 0,05 probability. To evaluate the amount of accumulated degree-days, a regression analysis was applied. One observed that the percentage of fastened fruits was similar, regardeless of the geographical quadrants, and was not influenced by the location of the branches in the canopy. Starting from the anthesis, 967,4 and 1338,4 accumulated degree-days were needed, respectively, for the stabilization of the fruit set and fruit maturation.

Index terms: Citrus latifolia, fruit development, fruit set; maturation.

\subsection{Introdução}

Os citros florescem profusamente, entretanto o número de frutos colhidos não superam $10 \%$ das flores formadas, alcançando, normalmente, valores entre 0,1 e 3,5\% (Agustí et al., 1982; Monselise, 1986).

Krezdorn (1986) definiu fixação como o estádio de desenvolvimento em que, a partir deste, provavelmente os frutos chegarão a maturação, excluindo posteriores abscisões causadas por estresse fisiológico, danos mecânicos ou devido a injúrias de pragas ou patógenos. Normalmente, a fixação ocorre após a queda fisiológica, disfunção decorrente da competição dos frutos em desenvolvimento por carboidratos, água e outros metabólitos, sendo entretanto, um processo intimamente regulado pelo balanço hormonal da planta (Powell \& Krezdorn, 1977).

A fixação de frutos vem sendo estudada, principalmente, em variedades cítricas que apresentam valores baixos de fixação ou que apresentam alternância de produção (Agustí \& Almela, 1991). Contudo, segundo Krajewisk \& Rabe (1995), ainda são poucos os trabalhos sobre o florescimento em citros relacionado a sua localização geográfica na copa. 
Os citros têm uma ampla distribuição geográfica, mostrando sua aptidão a diferentes condições climáticas, entretanto esta amplitude resulta em variações entre regiōes e entre anos, nas características fenológicas de florescimento e frutificação (Reuther, 1973).

O clima influencia, principalmente, na aptidão das variedades, na fenologia, como o período de florescimento, na curva de maturação, na taxa de crescimento, nas características físicas e químicas dos frutos e no potencial de produção (Ortolani et al., 1991; Davies \& Albrigo, 1994). As temperaturas abaixo de $13^{\circ} \mathrm{C}$ e acima de $35^{\circ} \mathrm{C}$ são consideradas limitantes ao crescimento vegetativo (Koller, 1994). Thompson et al. (1965) verificaram que a taxa fotossintética mostrou-se ótima na faixa compreendida entre 20 e $30^{\circ} \mathrm{C}$.

A relação existente entre 0 desenvolvimento dos frutos cítricos e 0 acúmulo de graus-dias, vem sendo estudada em diferentes variedades (Reuther, 1973; Kimball, 1984; Ortolani et al., 1991; Volpe, 1992; Sentelhas, et al., 1997). Sam et al. (1988), citados por Sentelhas et al. (1997), obtiveram em Cuba, entre o florescimento e a maturação de frutos de limeira ácida 'Tahiti', 1220 graus-dias acumulados.

Existem poucos relatos sobre frutificação e período de maturação em limeira ácida 'Tahiti'. Portanto, neste experimento avaliou-se a porcentagem de fixação de frutos de limeira ácida 'Tahiti' nos diferentes quadrantes geográficos da copa, relacionando-se a quantidade de graus-dias acumulados necessária para a fixação e a maturação de frutos, nas condições de Piracicaba, São Paulo.

\subsection{Material e métodos}

O experimento foi conduzido em condição de campo, na Universidade de São Paulo, Escola Superior de Agricultura "Luiz de Queiroz", Fazenda Areão, no município de Piracicaba, localizado a $22^{\circ} 43^{\prime \prime}$ de latitude Sul e $47^{\circ} 38^{\prime \prime}$ de 
longitude Oeste, em uma altitude média de $\mathbf{5 7 6}$ metros acima do nível do mar. O clima da região é do tipo Cwa, segundo a classificação de Köppen (1948), ou seja, tropical úmido, com inverno seco e verão chuvoso; apresentado temperatura média de $21,1^{\circ} \mathrm{C}$, precipitação anual de $1.253 \mathrm{~mm}$, umidade

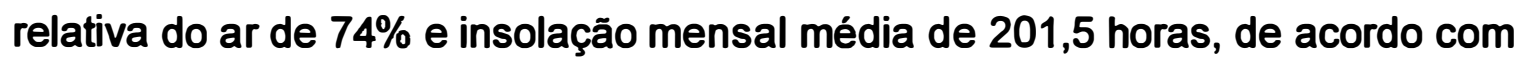
a Estação Agrometeorológica da USP/ESALQ/Departamento de Ciências Exatas, em Piracicaba-SP.

Utilizou-se limeiras ácidas 'Tahiti' (Citrus latifolia Tanaka), com sete anos de idade enxertadas em limoeiro 'Cravo' (Citrus limonia L. Osbeck), espaçadas de 8,0 x 5,0 metros, cultivadas, sob regime de irrigação por microaspersão. 0 solo da área experimental é classificado como em terra roxa estruturada eutrófica; A moderado, textura argilosa sobre muito argilosa (correspondente ao Kandiudalfic Eutrudox) (Vidal-Torrado \& Sparovek, 1993).

Por ocasião da florada, na segunda quinzena de Outubro de 1997, foram selecionadas 16 plantas, adotando-se um delineamento experimental em blocos inteiramente casualizados, constando quatro plantas em quatro blocos, sendo marcados dois ramos florais por quadrante geográfico [Norte (N), Sul (S), Leste (L), Oeste (O)] por planta, no estádio fenológico de antese.

Determinou-se a porcentagem de fixação de frutos nos diferentes quadrantes geográficos da copa, através de contagem semanal do número de flores e frutos em cada ramo previamente marcado, desde a antese até a maturação dos frutos. Considerou-se o fruto maduro quando os valores de "ratio" e diâmetro mínimo alcançaram 1,5 e $40 \mathrm{~mm}$, respectivamente (Figueiredo, 1991).

As observaçöes foram relacionadas aos graus-dias acumulados nas semanas e no período, através da fórmula descrita por Volpe (1992): 


$$
G D=\left[\left(T_{\max }+T_{\min }\right) / 2\right]-T b
$$

Sendo, GD: graus-dias; $T_{\max }$. temperatura máxima; $T_{\min }$ : temperatura mínima; Tb: temperatura base $\left(13^{\circ} \mathrm{C}\right.$, para citros).

Os dados obtidos foram submetidos à analise de variância e as médias comparadas através do teste de Tukey a 0,05 de probabilidade para a porcentagem média de frutos fixados e análise de regressão para a quantidade de graus-dias acumulados.

\subsection{Resultados e discussão}

Na Tabela 1 consta a análise da variância e teste $F$ da porcentagem média de frutos fixados em relação aos quadrantes geográficos da copa e graus-dias acumulados. Observa-se que não houve diferença significativa entre os diferentes quadrantes geográficos da copa (Norte, Sul, Leste, Oeste). Esses resultados ratificam àqueles reportados por Rocha et al. (1990), que para as variedades de laranjeiras doces (Citrus sinensis L. Osbeck) 'Pera', 'Baianinha', 'Valência' e 'Natal', não observaram diferenças significativas da porcentagem de frutos fixados entre os quadrantes geográficos da copa.

Ressalta-se que a relação entre a porcentagem média de frutos fixados nos diferentes quadrantes geográficos da copa com o acúmulo de graus-dias não apresentou significância estatística (Tabela 1), ou seja, as curvas de porcentagem média de fixação nos diferentes quadrantes, tiveram comportamento semelhante durante todo o período avaliado. Esse comportamento apresentou similaridade àquele observado em laranjeira doce 'Pera' por Araújo et al. (1999). 
Tabela 1. Análise da variância e teste $F$ para a variável porcentagem média de frutos fixados, em função dos fatores quadrantes geográficos da copa e graus-dias acumulados (observações transformadas com $\operatorname{arcosen} \sqrt{x / 100}$ ). Piracicaba-SP, 1998.

\begin{tabular}{l|c|c}
\hline Causas de Variação & G.L. & QM \\
\hline Blocos & 3 & 92,019 \\
Quadrantes & 3 & $106,488^{\text {ns }}$ \\
Resíduo (A) & 9 & 192,963 \\
\hline (Parcelas) & $(15)$ & \\
Graus-dias & 14 & $4629,963^{\star *}$ \\
Quadrantes x Graus-dias & 42 & $13,209^{\text {ns }}$ \\
Resíduo (B) & 168 & 20,047 \\
\hline Total & 239 & \\
\hline Coeficiente de Variação (A) & & $19,692 \%$ \\
Coeficiente de Variação (B) & & $24,582 \%$ \\
\hline
\end{tabular}

** = significativo pelo teste $F$ a 0,01 de probabilidade $(\alpha \leq 0,01)$.

ns $=$ não significativo pelo teste $F$, para um n.m.s. de $0,05(\alpha>0,05)$.

Em relação aos graus-dias acumulados semanalmente, observou-se diferença significativa entre as coletas, ressaltando a influência da amplitude de temperatura ocorrida durante o período experimental.

$\mathrm{Na}$ Tabela 2 constam as médias originais e ajustadas pelas equações quadrática e exponencial, para a porcentagem média de frutos fixados em função dos graus-dias acumulados. Percebe-se que a interação porcentagem de frutos fixados e graus-dias acumulados, apresentou um ajuste $\left(R^{2}\right)$ para a regressão quadrática maior que a exponencial. Entretanto, a regressão exponencial (Figura 1), na prática e com a observação dos dados originais que tendem a uma estabilização durante o período avaliado, explica melhor o fenômeno do que a quadrática, para a qual foram estimados alguns valores negativos, que devem ter ocorrido pela variação do acaso (fator não observado) em campo, os quais não devem ser considerados para inferências posteriores. 
Tabela 2. Médias originais e ajustadas pelas equações quadrática e exponencial, para a porcentagem média de frutos fixados em função dos graus-dias acumulados. Piracicaba-SP, 1998.

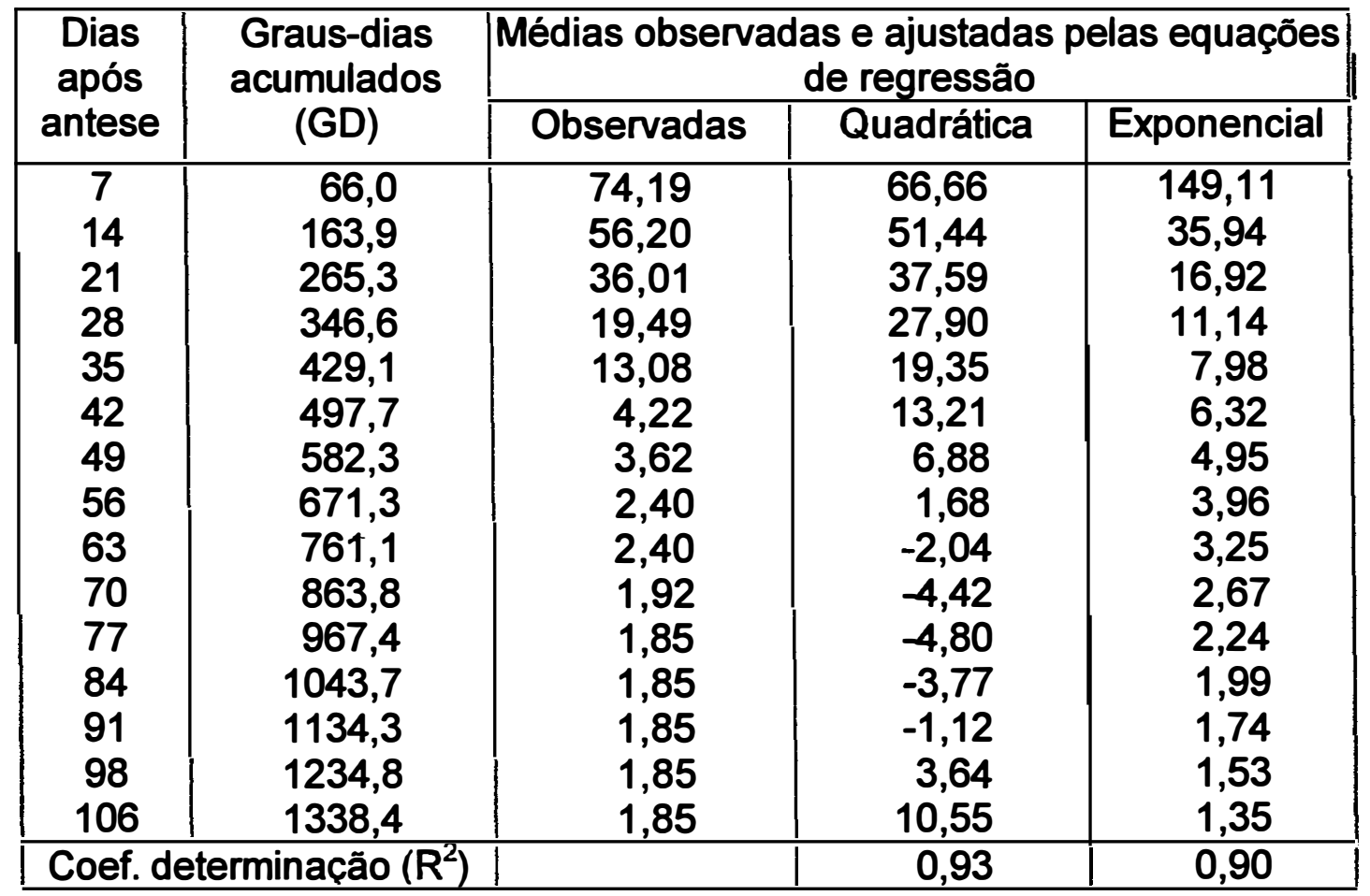

Percebe-se na Tabela 2 que a abscisão de frutos foi acentuada até, aproximadamente, o acúmulo de $\mathbf{5 0 0}$ graus-dias (GD), $\mathbf{4 2}$ dias após a antese, quando a porcentagem média de frutos fixados foi de $4,22 \%$, entretanto, a partir de 967,4 GD, 77 dias após a antese, a porcentagem média de frutos fixados manteve-se constante $(1,85 \%)$, até o período de maturação dos frutos.

Observa-se um acúmulo de 1338,4 graus-dias, referentes a 106 dias entre a antese e a maturação dos frutos (Tabela 2). Esse valor aproximou-se daquele obtido por Sam et al. (1988), 1220 GD, citados por Sentelhas et al. (1997), em limeiras ácidas 'Tahiti' cultivadas nas condições de Cuba. 


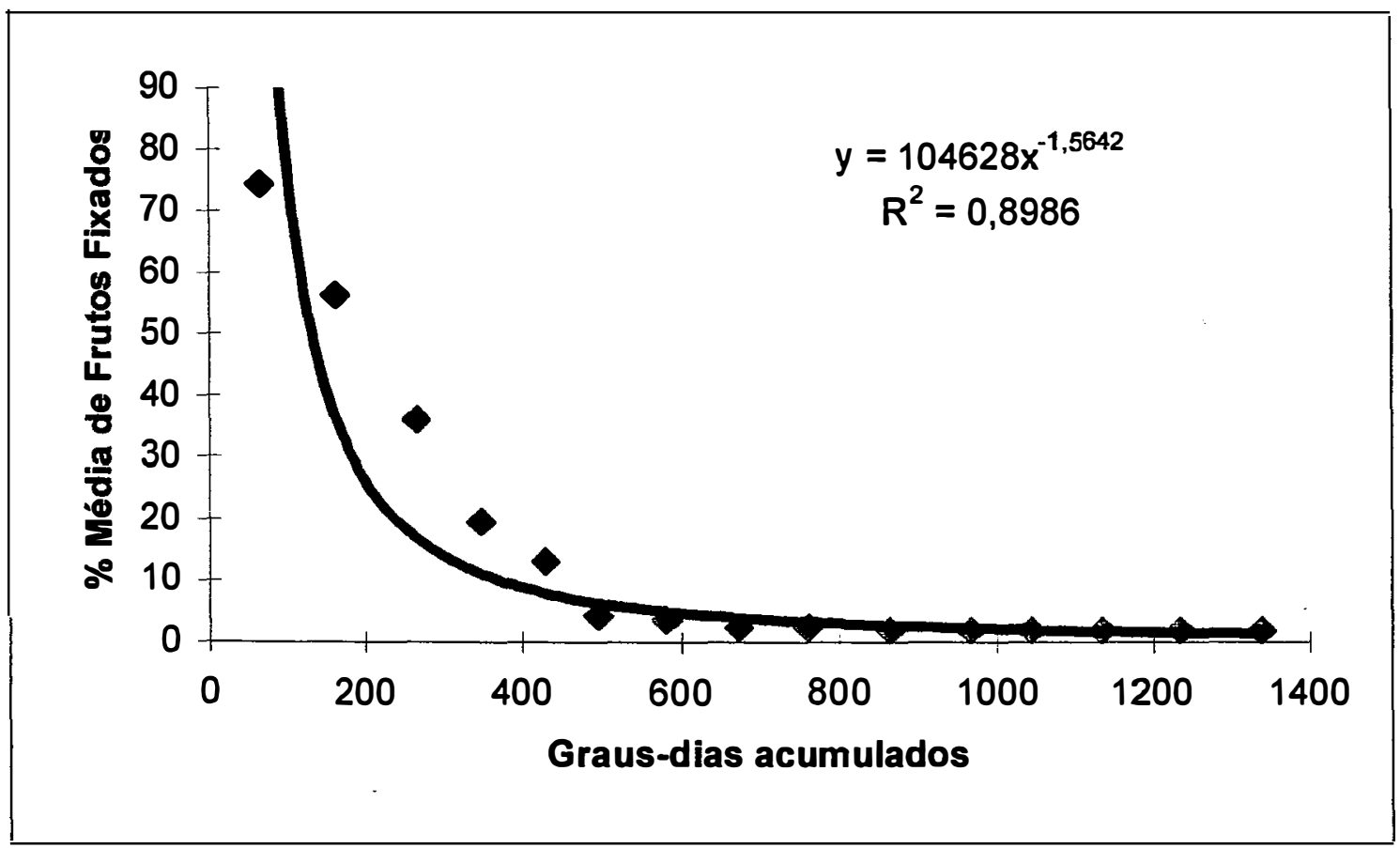

FIGURA 1. Diagrama de dispersão e função ajustada para a porcentagem média de frutos fixados em função dos graus-dias acumulados. Piracicaba-SP, 1998.

Esse resultado torna-se importante ao passo em que o somatório de temperaturas ocorridas desde a floração até a maturação dos frutos alcança valores que são constantes para cada variedade, podendo-se, portanto, estimar para cada região, o período que decorrerá desde o florescimento até a maturação dos frutos nas diferentes variedades citricas (Koller, 1994).

Nota-se na Tabela 2 que a relação entre graus-dias acumulados para a fixação $(G D F=967,4)$ e maturação $(G D M=1338,4)$ de frutos é de 0,72 (GDF/GDM), aproximando-se a $3 / 4$ da quantidade total de graus-dias necessários para am aturação dos frutos. 


\subsection{Conclusões}

Nas condições deste experimento observou-se que a porcentagem média de frutos fixados apresentou comportamento similar, independentemente dos quadrantes geográficos, não sendo influenciada pela localização dos ramos na copa. A partir da antese, para a estabilização da fixação $(1,85 \%)$ e maturação de frutos, foram necessários 967,4 e 1338,4 graus-dias acumulados, respectivamente. 


\title{
4 SEGUNDO TRABALHO CIENTÍFICO
}

\section{FIXAÇÃO DE FRUTOS DE LIMEIRAS ÁCIDAS ‘TAHITI’ COM APLICAÇÃO DE ÁCIDO GIBERÉLICO EM FLORADA FORA DE ÉPOCA E SUA RELACÃO AO ACÚMULO DE GRAUS-DIAS.}

\begin{abstract}
MARCEL BELLATO SPÓSITO; FRANCISCO DE ASSIS ALVES MOURÃO FILHO $^{78}$, PAULO SÉRGIO RODRIGUES DE ARAÚJO ${ }^{9}$
\end{abstract}

\section{Resumo}

Avaliou-se a porcentagem média de fixação de frutos de limeiras ácidas 'Tahiti', com oito anos de idade, enxertadas em limoeiro 'Cravo', cultivadas no espaçamento de $8,0 \times 5,0$ metros, aplicando-se no período de antese, diferentes concentrações de ácido giberélico $\left(0,10,25,50\right.$ e $\left.100 \mathrm{mg}^{-1} \mathrm{~L}^{-1}\right)$, em florada fora de época (março/98), estimando-se o acúmulo de graus-dias para a fixação e maturação de frutos, nas condições de Piracicaba-SP. Adotou-se o delineamento experimental em blocos casualizados, sendo determinada a

${ }^{6}$ Pesquisador Científico do Fundecitrus. Pós-graduando do Depto.de Produção Vegetal ESALQ/USP, bolsista Capes.

${ }^{7}$ Prof. Dr. Depto. de Produção Vegetal - ESALQ/USP. C.P. 09, CEP 13418-900, Piracicaba-SP. Bolsista CNPq.

${ }^{7}$ Pós-graduando do Depto.de Produção Vegetal - ESALQ/USP. 
porcentagem média de fixação de frutos, através de contagem semanal do número de flores e frutos em cada ramo previamente marcado, desde a antese até a maturação dos frutos. Os dados obtidos de percentual médio de fixação e graus-dias acumulados foram submetidos a análise de regressão. Em relação a fixação de frutos, observou-se que $10 \mathrm{mg} . \mathrm{L}^{-1}$ de $\mathrm{GA}_{3}$ foram suficientes para fixar mais de $10 \%$ de frutos, em relação ao número de flores formadas, representando um incremento superior a 25 vezes, em relação à testemunha. A partir da antese, para a estabilização da fixação e maturação de frutos, foram necessários 837,7 e 1115,2 graus-dias acumulados, respectivamente.

Palavras-chave: Citrus latifolia, frutificação, maturação, fixação, regulador vegetal

\section{Summary}

\section{FRUIT-SET AT 'TAHITI' LIME RELATING THE GIBBERELLIC ACID APPLICATION IN OUT-OF-SEASON FLOWERING AND ITS RELATIONSHIP TO THE ACCUMULATED DEGREE-DAYS}

The percentage of 'Tahiti' limes budded on 'Rangpur' lime with eight years of age and cultivated, in 8,0 x 5,0 m spacing was evaluated, relating the gibberellic acid application in out-of-season flowering and its relationship with the accumulated degree-days. Five different concentrations of gibberellic acid $\left(0,10,25,50\right.$ and $\left.100 \mathrm{mg} . \mathrm{L}^{-1}\right)$ were applied in the anthesis period and with the accumulation of degree-days for fruit set and fruit development in the conditions of Piracicaba county, in the state of São Paulo, Brazil. The statitical design 
consisted of randomized blocks being and the percentage of fruit set was determined through weekly counts of the number of flowers from the anthesis to the maturation of the fruit, in each branch previously marked. The obtained data of percentage of fruit set and the degree-days accumulated were submitted to regression analysis. In relation to fruit set of fruit, one observed that $10 \mathrm{mg} . \mathrm{L}-1$ of gibberellic acid were enough to fasten more than $10 \%$ of fruits, in relation to the number of formed flowers, representing to set more than 25 times of flowers shaped. Starting from the anthesis, 837,7 and 1115,2 accumulated degree-days were necessary for the stabilization of fruit set and maturation, respectively.

Index term: Citrus latifolia, fruit development, fruit set, maturation, growth regulator.

\subsection{Introdução}

A abscisão de flores e frutos que ocorre após a florada é resultado, principalmente, da competição destes por carboidratos, água e outros metabólitos, sendo este um processo regulado pelo balanço hormonal da planta (Powell \& Krezdorn, 1977). O número de frutos colhidos não superam $10 \%$ das flores formadas, alcançando, normalmente, valores entre 0,1 a 3,5\% (Agusti et al., 1982; Monselise, 1986).

Em variedades que apresentam sementes, a polinização e posterior fertilização, são fundamentais na fixação de frutos, pois aumentam os niveis endógenos de hormônios vegetais, principalmente as giberelinas, as quais aumentam a força de dreno por fotoassimilados e minerais, reduzindo assim a abscisão de ovários e frutos em desenvolvimento (Talón et al., 1997; BemCheikh et al., 1997). Em variedades partenocárpicas, o estímulo é atribuído às paredes do ovário, onde ocorre a sintese de receptores dos fatores que regulam a fixação dos frutos (Monselise 1977). Em variedades que apresentam 
sementes, a fixação ocorre com facilidade e, às vezes, em excesso, podendo desencadear a alternância de produção (Spósito et al., 1998).

A aplicação exógena de ácido giberélico tem mostrado bons resultados, na fixação de frutos, principalmente em tangerineiras e em seus híbridos (Agustí \& Almela, 1991; Castro, 1998). Entretanto, uma resposta positiva a uma aplicação exógena desse regulador vegetal só é obtida quando a aplicação é realizada em um momento de máxima sensibilidade e o conteúdo endógeno desse hormônio apresenta-se em concentrações menores do que as necessárias para determinadas respostas (Agusti \& Almela, 1991).

Em relação a fixação de frutos, a máxima resposta é obtida quando aplica-se o ácido giberélico no período compreendido entre a antese e a queda de pétalas (Garcia-Martínez \& Garcia-Papí, 1979; Castro, 1998).

A relação existente entre 0 desenvolvimento de frutos cítricos e 0 acúmulo de graus-dias, vem sendo estudado (Reuther, 1973; Kimball, 1984; Ortolani et al., 1991; Volpe, 1992; Sentelhas et al., 1997). Esta relação torna-se importante na medida em que a cultura desenvolve-se em diferentes microclimas.

Sam et al. (1988), citados por Sentelhas et al. (1997), obtiveram, em Cuba, um valor de 1220 graus-dias acumulados entre o florescimento e a maturação de frutos de limeira ácida 'Tahiti'.

Portanto, neste experimento avaliou-se a fixação média de frutos de limeira ácida 'Tahiti' com aplicação exógena de ácido giberélico em florada fora de época, estimando-se a quantidade de graus-dias necessária para a fixação e maturação dos frutos.

\subsection{Material e métodos}

O experimento foi conduzido em condição de campo, na Universidade de São Paulo, Escola Superior de Agricultura "Luiz de Queiroz", Fazenda Areão, 
no município de Piracicaba, localizado a $22^{\circ} 43^{\prime \prime}$ de latitude Sul e $47^{\circ} 38^{\prime \prime}$ de longitude Oeste, em uma altitude média de $\mathbf{5 7 6}$ metros acima do nível do mar. Segundo a classificação de Köppen (1948), o clima da região é do tipo Cwa, ou seja, tropical úmido, com inverno seco e verão chuvoso; apresentado temperatura média de $21,1^{\circ} \mathrm{C}$, precipitação anual de $1.253 \mathrm{~mm}$, umidade relativa do ar de $74 \%$ e insolação mensal média de 201,5 horas, de acordo com a Estação Agrometeorológica da USP/ESALQ/Departamento de Ciências Exatas, em Piracicaba-SP.

Utilizou-se limeiras ácidas 'Tahiti' (Citrus latifolia Tanaka), com oito anos de idade enxertadas em limoeiro 'Cravo' (Citrus limonia L. Osbeck), espaçadas de 8,0 x 5,0 metros, cultivadas sob regime de irrigação por microaspersão. 0 solo da área experimental é classificado como em terra roxa estruturada eutrófica; A moderado, textura argilosa sobre muito argilosa (correspondente ao Kandiudalfic Eutrudox) (Vidal-Torrado \& Sparovek, 1993).

Por ocasião de florada fora de época (entressafra), na segunda quinzena de março de 1998, foram selecionadas 40 plantas, onde os tratamentos foram aplicados, através de pulverização localizada nos ramos marcados, no volume de $0,5 \mathrm{~L}$. ramo ${ }^{-1}$. O delineamento experimental adotado foi em blocos inteiramente casualizados, com quatro repetiçöes, constando cinco parcelas compostas por duas plantas, nas quais foram marcados quatro ramos florais por planta, no estádio fenológico de antese. Os tratamentos empregados foram: 0 (testemunha); 10; 25; 50 e $100 \mathrm{mg} . \mathrm{L}^{-1}$ de $\mathrm{GA}_{3}$.

Determinou-se a porcentagem média de fixação de frutos nos diferentes tratamentos, através de contagem semanal do número de flores e frutos desde a antese até a maturação, em cada ramo previamente marcado. Considerou-se frutos maduros quando alcançaram "ratio" de 1,5 e diâmetro mínimo de $40 \mathrm{~mm}$ (Figueiredo, 1991).

As observações foram relacionadas aos graus-dias acumulados nas semanas e no período, através do somatório diário, desde o período de antese até a maturação dos frutos, utilizando-se a fórmula descrita por Volpe (1992): 


$$
G D=\left[\left(T_{\max }+T_{\min }\right) / 2\right]-T b
$$

Sendo, GD: graus-dias; $T_{\text {max: }}$ temperatura máxima; $T_{\text {min: }}$ temperatura mínima; $\mathrm{Tb}$ : temperatura base $\left(13^{\circ} \mathrm{C}\right.$, para citros).

Os dados obtidos foram submetidos à analise de variância e as médias de porcentagem de frutos e a quantidade de graus-dias acumulados foram comparadas através de análise de regressão.

\subsection{Resultados e discussão}

Consta na Tabela 1 a análise da variância e teste $F$ para a variável porcentagem média de frutos fixados, em função dos fatores tratamentos (concentração de ácido giberélico) e graus-dias acumulados. Observa-se diferenças significativas ao nível de $1 \%$, pelo teste $F$, na porcentagem média de frutos fixados em relação aos tratamentos e aos graus-dias acumulados semanalmente, entretanto, na interação desses dois fatores não ocorreu significância.

A relação entre a porcentagem média de frutos fixados nas diferentes concentraçōes de ácido giberélico exógeno associado ao acúmulo de grausdias não foi estatisticamente diferente, ou seja, as curvas de fixação média dos frutos em relação ao tratamentos adotados apresentaram comportamento semelhante durante todo o período avaliado.

Em relação aos graus-dias acumulados semanalmente, observa-se na Tabela 1, que houve diferença significativa entre as coletas semanais, ressaltando a influência da amplitude de temperatura ocorrida durante o período experimental. 
Tabela 1. Análise da variância e teste $F$ para a variável porcentagem média de frutos, em função dos fatores tratamentos e graus-dias acumulados (observaçōes transformadas com arco sen $\sqrt{x / 100}$ ). Piracicaba-SP, 1998.

\begin{tabular}{l|c|c}
\hline Causas de Variação & G.L. & QM \\
\hline Blocos & 3 & 583,966 \\
Tratamentos & 4 & $4342,303^{\star *}$ \\
Resíduo (A) & 12 & 598,941 \\
\hline (Parcelas) & $(19)$ & \\
Graus-dias & 22 & $3309,687^{\star \star}$ \\
-Tratamentos x Graus-dias & 88 & $13,725^{\text {ns }}$ \\
Resíduo (B) & 330 & 10,902 \\
\hline Total & 459 & \\
\hline Coeficiente de Variação (A) & & $23,644 \%$ \\
Coeficiente de Variação (B) & & $15,298 \%$ \\
\hline
\end{tabular}

** = Significativo, pelo teste $F$, ao nivel de $1 \%(\alpha \leq 0,01)$.

ns $=$ Não significativo pelo teste F, para um n.m.s. de $5 \%(\alpha>0,05)$.

Através dos resultados obtidos pela análise de regressão, utilizando-se a equação de Mitscherlich (Figura 1), observou-se que a concentração de 10 $\mathrm{mg} . \mathrm{L}^{-1}$ de ácido giberélico foi suficiente para aumentar a porcentagem média de fixação de frutos de limeira ácida 'Tahiti'. Essa concentração é recomendada em pomares comerciais, na África do Sul e Espanha, para a variedade de tangerineira 'Clementina' (Lange et al., 1982; Agusti \& Almela, 1991).

Entretanto, através da curva ajustada, para essa equação, percebe-se que com a concentração de aproximadamente $3 \mathrm{mg} \cdot \mathrm{L}^{-1}$ de ácido giberélico obtem-se a máxima porcentagem média de fixação de frutos (Figura 1). Essa concentração aproxima-se do valor recomendado na Espanha para a fixação de frutos de tangerineiras 'Clemenules' $\left(2,5 \mathrm{mg} \cdot \mathrm{L}^{-1}\right.$ de ácido giberélico), cujas 
plantas apresentam florações fora de época, assegurando a fixação de uma parte importante dessas flores (Agustí \& Almela, 1991).

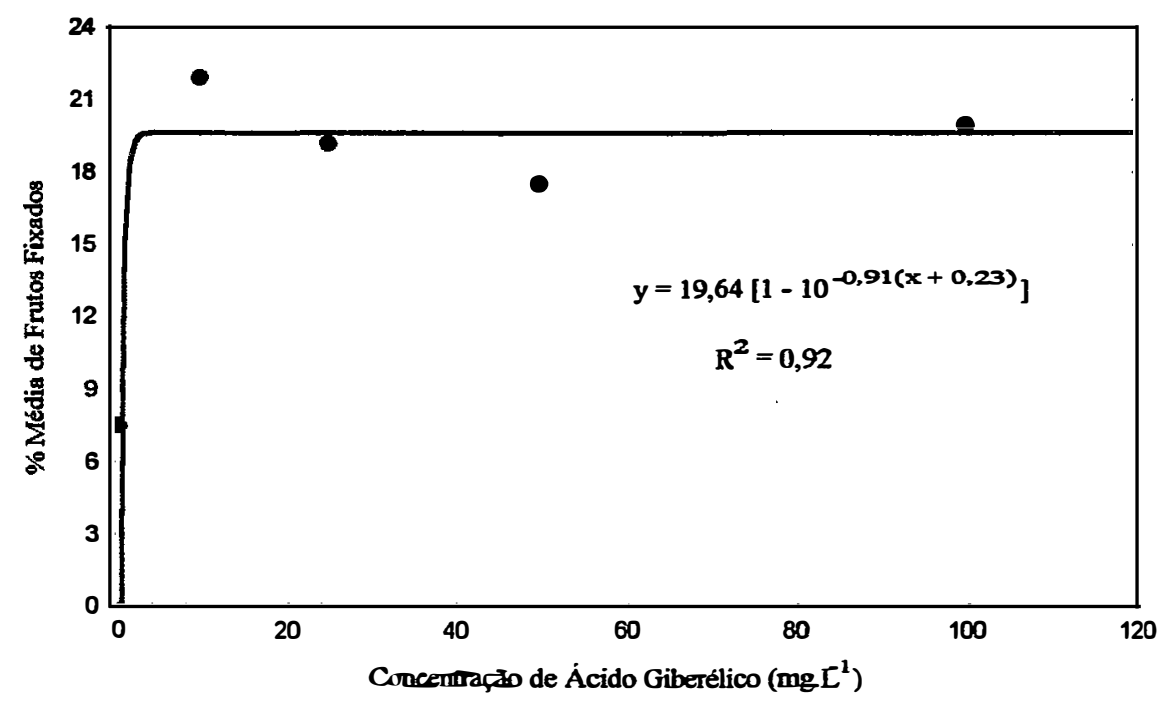

Figura 1. Diagrama de dispersão e função ajustada para médias de porcentagem de frutos fixados de limeira ácida 'Tahiti' em função das concentrações de ácido giberélico. Piracicaba-SP, 1998.

O valor estimado de ácido giberélico disponivel na planta de forma assimilável, através da equação de Mitscherlich foi igual a $0,23 \mathrm{mg} \cdot \mathrm{L}^{-1}$, para um coeficiente de eficácia igual a 0,91.

Na Figura 2 pode-se observar aos valores absolutos da porcentagem de frutos fixados nas diferentes concentrações de ácido giberélico. Percebe-se maior eficácia $(12,72 \%)$ na concentração de $10 \mathrm{mg} \cdot \mathrm{L}^{-1}$ de $G A_{3}$, promovendo resultado 25 vezes superior aquele obtido na testemunha $(0,46 \%)$. 


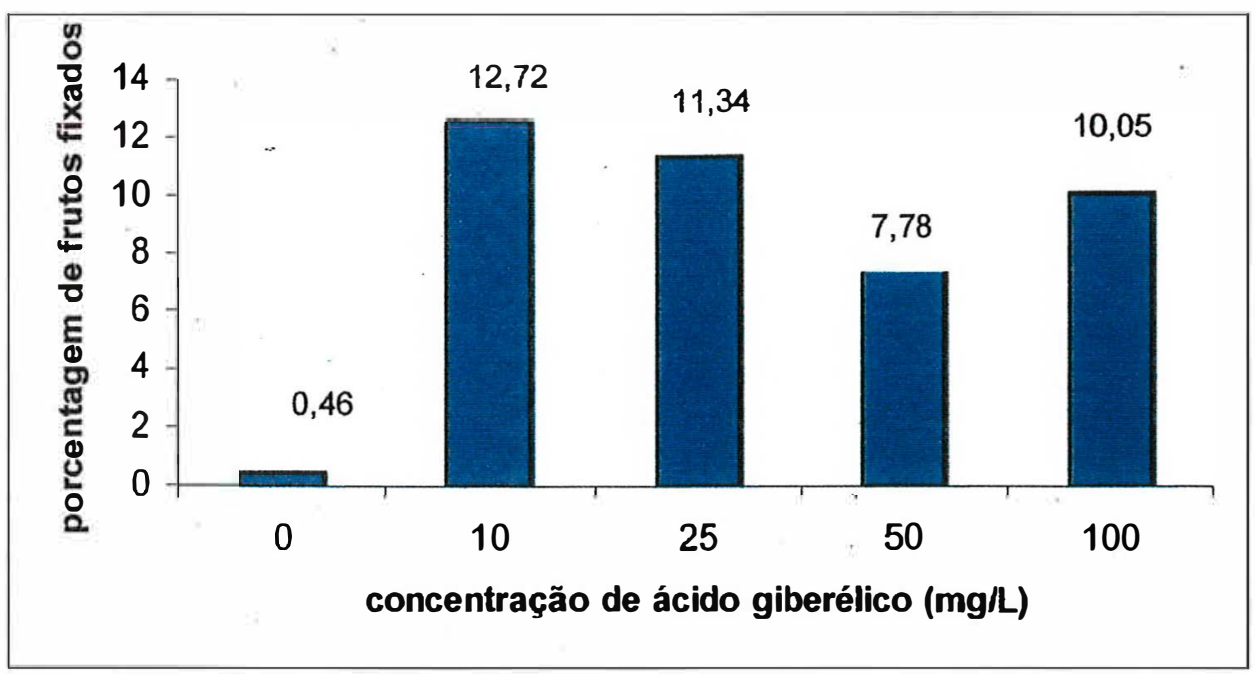

Figura 2. Diagrama de dispersão para as médias de porcentagem de frutos fixados de limeira ácida 'Tahiti' em função das concentrações de ácido giberélico. Piracicaba-SP, 1998.

$\mathrm{Na}$ Tabela 2 encontra-se as médias originais e ajustadas pelas equações quadrática e exponencial, para a porcentagem média de frutos fixados em função dos graus-dias acumulados. Observa-se que para a maturação dos frutos de limeira ácida 'Tahiti' foram necessários o acúmulo de 1115,2 grausdias (GD). Esse valor mostra-se próximo aos $1220 \mathrm{GD}$, obtidos por Sam et al. (1992) citados por Sentelhas et al. (1998), em Cuba.

Na Tabela 2 e Figura 3, nota-se que em torno dos 500 graus-dias acumulados, 56 dias após a antese, quando a porcentagem média de frutos fixados estava em $9,41 \%$, ocorreu uma diminuição acentuada na abscisão de frutos, entretanto, a fixação dos frutos estabilizou-se $(6,47 \%)$ a partir de 837,7 graus-dias acumulados, aos 126 dias após a antese até o período de maturação dos frutos. 
Tabela 2. Médias originais e médias ajustadas pelas equaçōes quadrática e exponencial, para a porcentagem média de frutos fixados em função dos graus-dias acumulados, em florada fora de época. PiracicabaSP, 1998.

\begin{tabular}{|c||c||c|c|c||}
\hline \multirow{2}{*}{$\begin{array}{c}\text { Dias } \\
\text { após } \\
\text { antese }\end{array}$} & $\begin{array}{c}\text { Graus-dias } \\
\text { acumulados } \\
\text { (GD) }\end{array}$ & $\begin{array}{r}\text { Médias observadas e ajustadas pelas } \\
\text { equaçoses de regressão }\end{array}$ \\
\cline { 3 - 5 } & Observadas & Quadrática & Exponencial \\
\hline 7 & 94,7 & 78,81 & 66,62 & 82,72 \\
14 & 157,4 & 61,07 & 55,91 & 45,65 \\
21 & 216,8 & 45,70 & 46,69 & 31,38 \\
28 & 302,4 & 20,91 & 34,98 & 21,26 \\
35 & 366,7 & 15,67 & 27,41 & 16,97 \\
42 & 424,5 & 12,61 & 21,50 & 14,30 \\
49 & 457,2 & 11,02 & 18,54 & 13,11 \\
56 & 500,8 & 9,41 & 15,00 & 11,78 \\
63 & 542,9 & 8,52 & 12,05 & 10,72 \\
70 & 595,2 & 8,19 & 9,01 & 9,63 \\
77 & 621,0 & 7,80 & 7,77 & 9,16 \\
84 & 647,1 & 7,51 & 6,68 & 8,73 \\
91 & 680,8 & 7,31 & 5,54 & 8,23 \\
98 & 705,2 & 7,01 & 4,89 & 7,89 \\
105 & 742,3 & 6,98 & 4,19 & 7,43 \\
112 & 773,3 & 6,98 & 3,88 & 7,09 \\
119 & 790,7 & 6,98 & 3,81 & 6,91 \\
126 & 837,7 & 6,47 & 4,01 & 6,45 \\
133 & 889,8 & 6,47 & 4,89 & 6,01 \\
140 & 924,3 & 6,47 & 5,85 & 5,75 \\
147 & 982,0 & 6,47 & 8,13 & 5,36 \\
154 & 1050,3 & 6,47 & 11,93 & 4,95 \\
162 & 1115,2 & 6,47 & 16,63 & 4,62 \\
\hline Coef. determinação( $\left.R^{2}\right)$ & - & 0,93 & 0,94 \\
\hline & & & & \\
\hline
\end{tabular}

Esse resultado torna-se importante ao passo em que o somatório de temperaturas ocorridas desde a floração até a maturação dos frutos alcançam valores semelhantes para cada variedade. Assim, pode-se estimar, para cada região, o periodo que decorrerá desde o florescimento até a maturação dos frutos (Koller, 1994). 


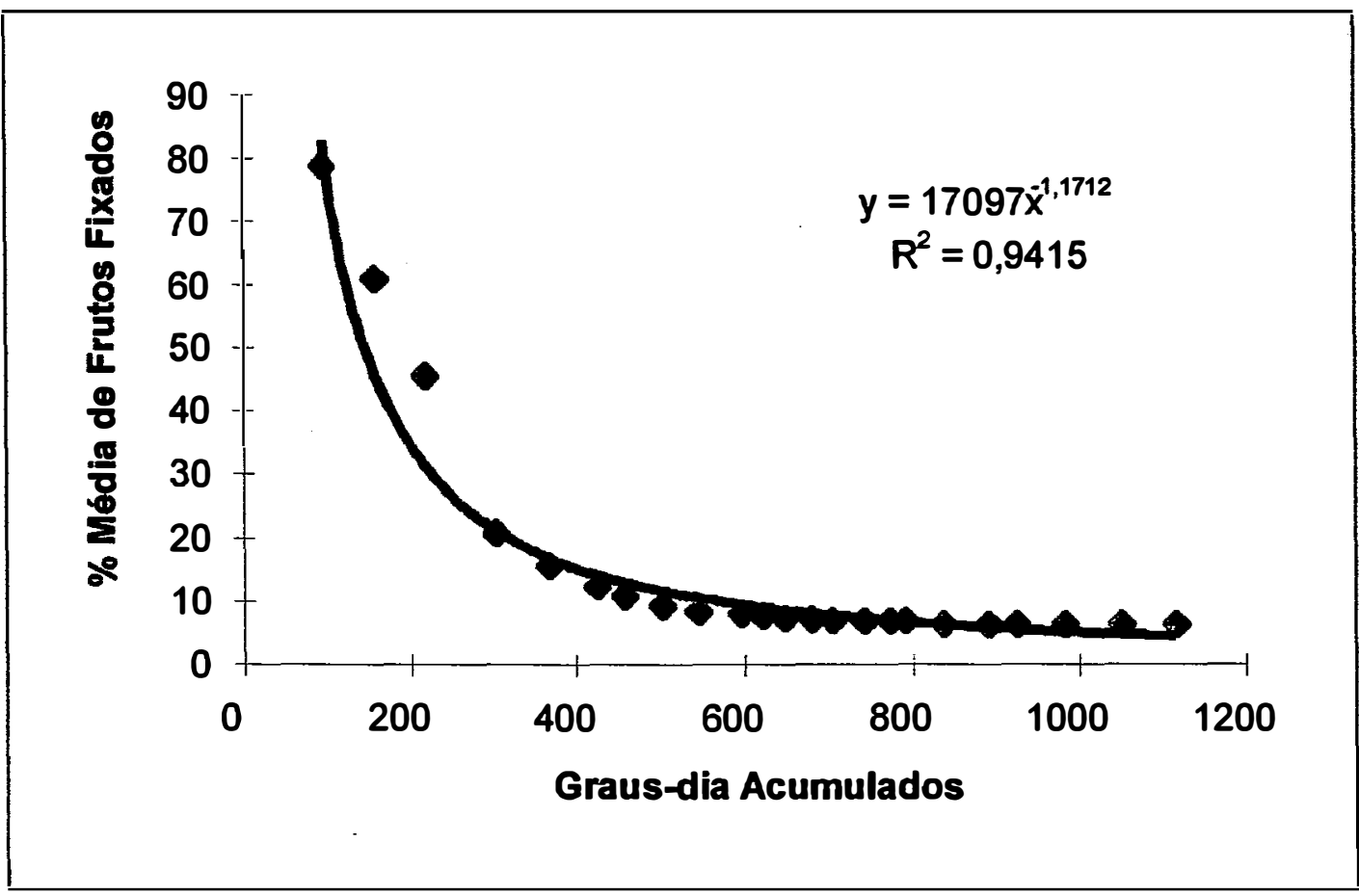

Figura 3. Diagrama de dispersão e função ajustada para a porcentagem média de frutos em função dos Graus-dia acumulados. Piracicaba-SP, 1998.

$\mathrm{Na}$ Tabela 2, observa-se que a relação entre graus-dias acumulados para a fixação (GDF=837,7) e para a maturação de frutos $(G D M=1115,2)$ foi de 0,75 (GDF/GDM), ou seja, $3 / 4$ da quantidade total de graus-dias necessários para a maturação dos frutos. 


\subsection{Conclusões}

Nas condições deste experimento observou-se que em relação a porcentagem média de frutos fixados, a aplicação de ácido giberélico $\left(\mathrm{GA}_{3}\right)$ na concentração de $10 \mathrm{mg} \cdot \mathrm{L}^{-1}$, mostrou-se suficiente para incrementar a fixação de frutos de limeira ácida 'Tahiti' em relação a testemunha em mais de 25 vezes $(12,72 \%$ e $0,46 \%$, respectivamente). A partir da antese, para a estabilização da fixação e maturação de frutos, foram necessários 837,7 e 1115,2 graus-dias acumulados, respectivamente. 


\section{CONCLUSÕES GERAIS}

De acordo com a avaliação da fixação média dos frutos de limeiras ácidas 'Tahiti', em relação aos diferentes quadrantes geográficos da copa, na florada de maior intensidade (safra) (Outubro/97), e a aplicação de ácido giberélico em diferentes concentrações, no período de florada fora de época (entressafra) (Março/1998), observou-se que não ocorreu influência dos quadrantes geográficos da copa das plantas, entretanto, a aplicação no período de antese de ácido giberélico na concentração de $10 \mathrm{mg} \cdot \mathrm{L}^{-1}$ de $G A_{3}$, foi suficiente para promover um incremento na porcentagem média de fixação dos frutos em mais de 25 vezes $(12,72 \%)$, quando comparada com a testemunha $(0,47 \%)$.

Considerando-se a quantidade de graus-dias (GD) acumulados para a fixação de frutos, nos períodos de safra e entressafra, foram necessários 967,4 e 837,7 GD, em 77 dias e 126 dias, respectivamente. Para a maturação de frutos, nos referidos períodos ocorreu um acúmulo de 1338,4 e 1115,2 GD, em 106 e 162 dias, respectivamente (Figura 1).

Figura 1. Graus-dias acumulados para os períodos de safra (outubro/97 a fevereiro/98) e entressafra (março/98 a agosto/98), entre a antese e maturação de frutos de limeira ácida 'Tahiti'. Piracicaba-SP, 1998.

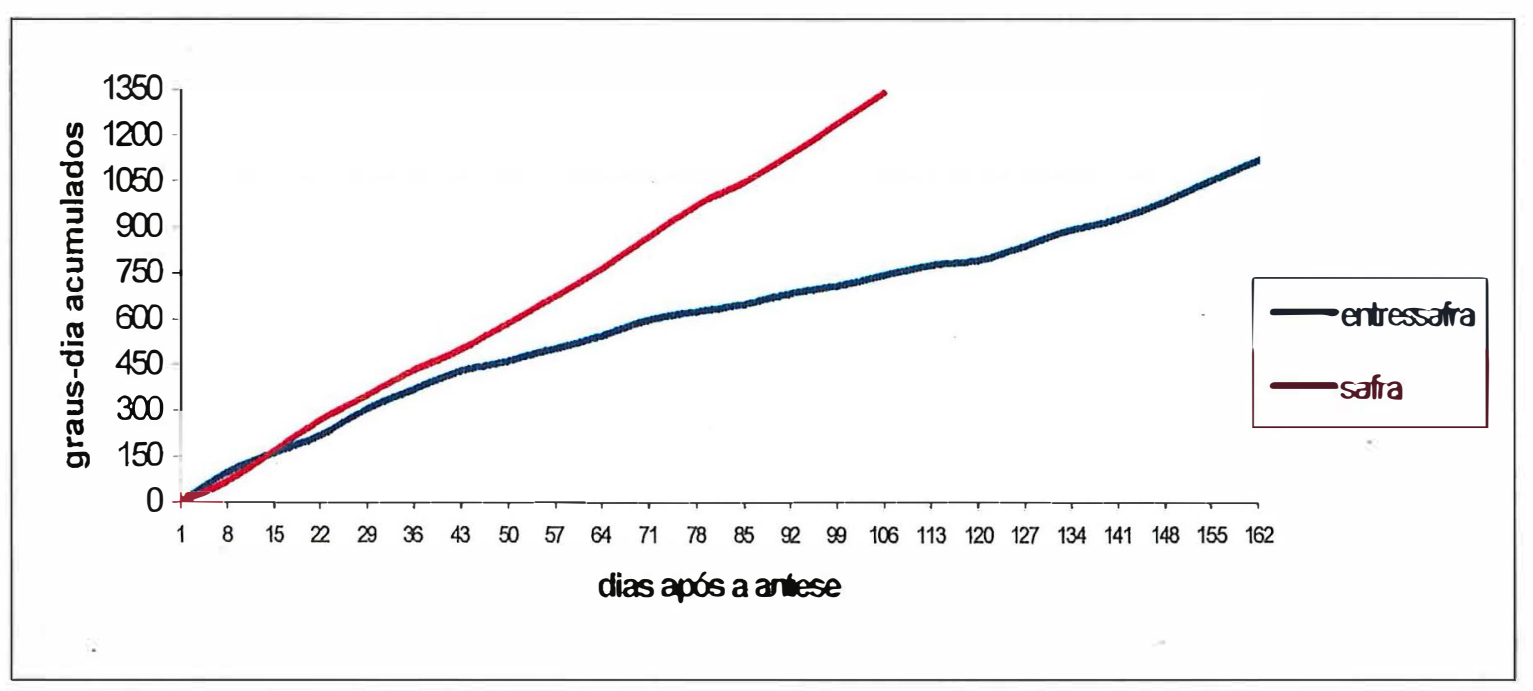


Quando comparada a quantidade de graus dias para a fixação (GDF) em relação a maturação de frutos (GDM), observou-se que na safra (GDF=967,4 e $\mathrm{GDM}=1338,4)$ obteve-se o valor de 0,72 (GDF/GDM) e para a entressafra (GDF=837,7 e GDM=1115,2) o valor de 0,75 (GDF/GDM). Em ambos os casos, a fixação ocorreu aproximadamente, com $3 / 4$ da quantidade de graus-dias acumulados necessária para a maturação de frutos. 


\section{REFERÊNCIAS BIBLIOGRÁFICAS}

AGUSTI, M. Floración y frutificación de los cítricos. In: SIMPÓSIO INTERNACIONAL DE FRUTICULTURA, 1., Botucatu, 1999. Anais., Botucatu: FAPESP, p.161-185,1999.

AGUSTI, M.; ALMELA, V. Aplicación de fitorreguladores en citricultura. Barcelona: AEDOS,1991. 261p.

AGUSTI, M; GARCIA-MARI, F.; GUARDIOLA, J. L. The influence of flower intensity on the shedding of reproductive strutures in sweet orange. Scientia Horticulturae, v.17, p.343-352, 1982.

ARAÚJO, P. S. R.; MOURÃO FILHO, F. A. A.; SPÓSITO, M. B. Pegamento de frutos de laranjeira 'Pera' em diferentes alturas na copa relacionado aos diferentes quadrantes geográficos. Scientia Agricola, Piracicaba, v.56, n.1, p.157-162, 1999.

BARBERA, G.; CARIMI, F. Effects of different levels of watwr stress on yield and quality of lemon trees. In: INTERNATIONAL CITRUS CONGRESS, 6., Tel Aviv, 1988. Proceedings., Tel Aviv, 1988, p.717-722.

BARCELÓ, J.; NICOLÁS, G.; SABATER, B.; SÁNCHEZ, R. Fisiología vegetal. Madrid: Ediciones Pirámide. 1992. 662p.

BARROS, C. B. Óleos essenciais cítricos do Brasil. Campinas: Fundação Cargill. 1986. 45p.

BELLOWS, T. S.; MORSE, J. G. Modelling flower development in navel oranges. Scientia Horticulturae, v.30, p.117-126, 1986. 
BEM-CHEIKH, W.; PÉRZ-BOTELLA, J.; TADEO, F. R.; TALÓN, M.; RIMOMILLO, E. Pollination increases gibberellin levels in developing ovaries of seeded varieties of citrus. Plant Physiology, v.114, p.557-564, 1997.

BERNIER, G.; BRONCHART,R.; KINET,J.M. Nucleiic acid synthesis and mitotic activity in the apical meristem of sinaps alba during flower induction. In: BERNIER, G. (Ed.) Cellular and molecular aspects of floral induction. London: Longman. 1970. p.51-76.

BOWER, J. P.; CUTTING, J. G. M.; LOVATT, C. J.; BLANKE, M. M. Interation of growth regulator and carbohydrate in flowering and fruit set. Acta Horticulturae, n.275, p.425-434, 1990. ब

BROSH, P.; MONSELISE, S. P. Increasing yields of 'Topaz' mandarin by gibberellin and girdling in the presence of 'Minneola' pollinizers. Scientia Horticulturae, v.7, p.369-372, 1977.

CASSIN, J.; BOURDEAUT, J.; FOUGUE, A .; FURON, V. GAILLARD, J. P.; LeBOURDELLES, J.; MONTAGUT, G.; MOREUIL, C. The influence of climate upon the blooming of citrus in tropical areas. In: INTERNATIONAL CITRUS SYMPOSIUM, 1.,Riverside, 1969. Proceedings., Riverside: University of California, 1969. v.1, p.315-323.

CASTRO, P. C. R. Reguladores vegetais na citricultura tropical. In: SEMINÁRIO INTERNACIONAL DE CITROS, 5., Bebedouro, 1998. Anais., Campinas: Fundação Cargill, 1998, p.463-479. '

CARRARO, A. F.; CUNHA, M. M. da. Manual de exportação de frutas. Brasília: FRUPEX, 1994. 254p. 
COELHO, Y. S. Lima ácida 'Tahiti’ para exportação. Brasília: FRUPEX, 1993. 35p. (FRUPEX. Publicações técnicas, 1).

CAETANO, A. A. Tratos culturais. In: RODRIGUEZ, O;; VIÉGAS, F. C. P. Citricultura brasileira. Campinas: Fundação Cargill, 1980. v.2, p.429-444.

CUÑAT, P.; GARCÍA, J. L.; CAROT, V.; PICÓ, F.; VAYÁ, J. L. Fitorreguladores en fruticultura. Aplicaciones de ácido giberélico $\left(\mathrm{GA}_{3}\right)$ y ácido 2,4,5triclorofenoxipropiónico para mejorar la produtividad del Clementino sin hueso. Revista Agroquímica e Tecnologia de Alimentos, v.14, p.106-112, 1974.

DAMIGELLA, P.; TRIBULATO, E.; CONTINELLA, G. Prove comparative com ácido gibberellico, incisione anulare e concimazione fogliare sul Clementine (Citrus clementina Hort.). Tecnologia Agricola. v.5, p.508-525, 1970.

DAVENPORT, T. L. Citrus flowering. Horticultural Reviews, v.12, p.349-408, 1990. ๑

DAVENPORT, T. L. Daminozide and gibberellin effects on floral induction of Citrus latifolia, HortScience, v.18, n.6, p.947-949, 1983.

DAVIES, F. S.; ALBRIGO, L. G. Citrus. Wallingford: CAB International, 1994. 254p.

DAVIES, F. S.; ISMAIL, M. A.; STOVER, E. W.; TUCKER, D. P. H.; WHEATON, T. A. Plant growth regulators. In: KNAPP, J. L (Ed.) 1999 florida citrus pest management guide, Gainesville: University. of Florida, 1998. 26.1-26.4p. 
DI GIORGI, F. Contribuição ao estudo do comportamento de algumas variedades de citros e suas implicações agroindustriais. Laranja, v.12, n.1, p.567-612, 1990.

DONADELLI, A.; COELHO, P. J.; NEGRI NETO, A.; SANTOS, Z. A. P. S.; CAMARGO FILHO, W. P. de; CAMARGO, M. L. B. Atividade agropecuária no Estado de São Paulo: distribuição e valor da produção por escritório de desenvolvimento rural. Informações Econômicas, v.27, n.12, p.21-31, 1997.

DONADIO, L. C.; FIGUEIREDO, J. O.; PIO, R. M. Variedades cítricas brasileiras. Jaboticabal: Funep, 1995. 228p.

DUARTE, A . M. M.; GUARDIOLA, J. L. Flowering and fruit set of 'Fortune' hybrid mandarin,. Effect of girdling and growth regulators. Proceedings of the International Society of Citriculture, v.2, p.1069-1071, 1996.

EL-OTMANI, M. Usos principais de reguladores de crescimento na produção de citros. In: SEMINÁRIO INTERNACIONAL DE CITROS, 2., Bebedouro, 1992. Anais., Bebedouro: Fundação Cargill, 1992. p.43-51.

EL-OTMANI, M.; LOVATT, C. J.; COGGINS Jr, C. W.; AGUSTÍ, M. Plant growth regulators in citriculture:factors regulating endogenous levels in citrus tissues. Critical Reviews in Plant Sciences, v.14, n.5, p.365-412, 1995.

ERICKSON, L. C. The general physiology of citrus. In: REUTHER, W; BATCHELOR, L. D.; WEBBER, H. J. (Ed.) The citrus industry. Riverside: University of California Press, 1968. v.2, p.86-126.

ERNER, Y.; BRAVDO, B. The importance of inflorescence leaves in fruit setting of 'Shamouti' orange. Acta Horticulturae, v.139, p.107-112, 1983. 
FIGUEIREDO, J. O. Variedades copa de valor comercial. In: RODRIGUEZ, O.; VIÉGAS,F.; POMPEU JR., J.; AMARO, A.. (Ed.) Citricultura brasileira. Campinas: Fundação Cargill, 1991. v.1, p. 239.

GARCIA-LUIS, A . Limitaciones en el uso de reguladores del desarollo en agricultura. In: GUARDIOLA, J. L. E MONERRI, C. (Ed.) Fisiología vegetal. Valencia: Universidad Politécnica de Valencia, 1987. p.171-186.

GARCÍA-MARTÍNEZ, J. L.; GARCÍA-PAPÍ, M. A. Influence of gibberellic acid on early fruit development, diffusible growth substances and content in of macronutrients in seedless Clementine mandarin. Scientia Horticulturae, v.11, p.337-347, 1979b.

GARCÍA-MARTÍNEZ, J. L.; GARCÍA-PAPI, M. A. The influence of gibberelic acid, 2,4-diclorophenoxyacetic acid and 6-benzylaminopurine on fruit-set of Clementine mandarin. Scientia Horticulturae, v.10, p.285-293, 1979a.

GIANFAGNA, T. J. Uses of natural and synthetic growth regulators. In: DAVIES, P. J. (Ed.) Plant hormones, physiology, biochemistry and molecular biology. Dordrecht: Kluwer Academic, 1995. p.751-773.

GOREN, R. Anatomical, physiological and hormonal aspects of abscission in Citrus. Horticultural Reviews, v. 15, p.33-46, 1993. 。

GUARDIOLA, J. L. , AGUSTI, M.; GARCIA-MARI, F. Gibberellic acid and flower bud development in sweet orange. Proceedings of the International Society of Citriculture, v.2, p.696-699, 1977. 
GUARDIOLA, J. L. Frutificação e crescimento. In: SEMINÁRIO INTERNACIONAL DE CITROS, 2., Bebedouro, 1992. Anais., Campinas: Fundação Cargill, 1992, p.1-26.

GUARDIOLA, J. L.; MONERRI, C.; AGUSTÍ, M. The inhibitory effect of gibberellic acid on flowering in Citrus, Physiologia Plantarum., v.55, p.136142, 1982.

HUBERMAN, M.; ZAMKI, E.; GOREN, R. Anatomical changes induced by ethylene in the abscission zone of citrus leaf and fruit explants. Israel Journal of Botany, v.37, p.107-121, 1988.

IWAHORI, S. Use of regulators in the control of cropping of mandarin varieties. Proceedings of the International Society of Citriculture, p. 263-270, 1978.

KIMBALL, D. A . Factors affecting the rate of maturation of citrus fruits. Proceedings of the Florida State of Horticultural Society, v.97, p.40-44, 1984.

KOLLER, O. C. Citricultura: laranja, limão e tangerina. Porto Alegre: Ed. Rígel, 1994. 446p.

KÖPPEN, W. Climatologia: com un estudio de los climas da tierra. Mexico: Fondo de Cultura Económica, 1948. 478p.

KRAJEWSKI, A. J.; RABE, E. Citrus flowering: A critical evaluation. Journal of Horticultural Science, v.70, n.3, p.357-374, 1995. ${ }^{\circ}$ 
KREZDORN, A . H.; BROWN, H. D. Increasing yields of the 'minneola, 'robinson' and 'osceola' varieties with gibberellic acid sprays and girdling. Proceedings of the Florida State for Horticultural Society, v.83, p.29-34, 1970.

KREZDORN, A . H.; JERNBERG, D. C. Field evaluation of growth regulators for fruit set. Proceedings of the International Society of Citriculture, v.2, p.660, 1977.

KREZDORN, A. H. Citrus flowering and fruit set. In: FERGUSON, J. J. (Ed.). Citrus flowering, fruit set and development. Gainesville: University of Florida, 1986. p.1-14. (Fruits Crops Development, 4).

LANGE, J.H.; PLESSIS, S.F.; VICENT, A .P.; PREEZ, M.B.; HOLMDEN, E. A .; RABE, E. Studies on Clementine yield, fruit size and mineral composition of leaves. Subtropica. v.3, p.7, 1982.

LENZ, F. Flower and fruitdevelopment in 'Valencia Late' oranges as affected by type of inflorescence and nutricional status. Horticultural Research, v.6, p.65-78, 1966.

LENZ, F.; KARNATZ, A. The effect of $\mathrm{GA}_{3}$, Alar and CCC on citrus cuttings. Acta Horticulturae, v.49, p.147-155, 1975.

LOMAS, J.; GAT, A.; SHIFRIN, B. Methods of forescasting the ripening dates of citros fruit in various regions of Israel. Agricultural Meteorology, v.7, p.321$327,1970$.

LÓPEZ, J. G. de O. Los reguladores de crescimento o fitohormonas. Aplicaciones prácticas en frutales. Hortofruticultura, v.3, n.64, 1993. 
LOVATT,C.; ZHENG, Y.; HAKE, K.D.. Demostration of a change in nitrogen metabolism in fluencing flower initiation in Citrus. Israel Journal of Botany, v.37, p.181-188, 1988.

MONSELISE, S. P. Citrus fruit development: endogenous systems and external regulation. Proceedings of the International Society of Citriculture, v.2, p.664-668, 1977.

MONSELISE, S. P. Citrus. In: MONSELISE, S. P. (Ed.) Handbook of fruit set and development. Boca Raton: CRC Press, 1986. p. 87-108.

MONSELISE, S. P.; GOLDSCHMIDT, E. E. Alternate bearing in the fruits trees. Horticultural Review, v. 4, p. 128-173, 1982.

MONSELISE, S. P.; GOLDSCHMIDT, E. E.; GOLOMB, A. Alternate bearing in citrus and ways of control. Proceedings of the International Society of Citriculture, v.1, p.239-242, 1981.

MOSS, G. I. Chemical control of flower development in sweet orange (Citrus sinensis). Australian Journal of Agricultural. Research, v. 21, p. 233-242, 1970.

MOSS, G. I. Temperature effects on flower initiation in sweet orange (Citrus sinensis). Australian Journal of Agricultural Research, v.27, p.399-407, 1976.

MOSS, G. I.; STEER, B. T.; KRIEDEMANN, P. E. The regulatory role of inflorescencne leaves in fruit-setting by sweet orange (Citrus sinensis). Physiologia Plantarum, v.27, p.432-438, 1972. 
NIR, I., GOREN, R.; LESHEM, B. Effect of water stress, gibberellic acid and 2chloroethyltrimethylammonium chloride (CCC) on flower differention in 'Eureka'lemon trees. Journal of the American Society for Horticultural Science, v.97, n.6, p.774-778, 1972.

ORTOLANI, A . A .; PEDRO J. R.; ALFONSI, R. R. Agroclimatologia e o cultivo dos citros. In: RODRIGUEZ, O.; VIÉGAS,F.; POMPEU JR., J.; AMARO, A.. (Ed.) Citricultura brasileira. Campinas: Fundação Cargill. 1991. v.1, p. 153188.

POWELL, A . A .; KREZDORN, A . H.. Influence of fruit-setting treatment on translocation of $14 \mathrm{C}$-metabolites in citrus during flowering. Journal of the American Society for Horticultural Science, v.102, p.709-714, 1977.

RAGONE, M. L. Os reguladores de crescimento no cultivo cítrico na Argentina. In: SEMINÁRIO INTERNACIONAL DE CITROS, 2., Bebedouro, 1992. Anais., Campinas: Funadação Cargill. 1992. p.52-66.

RAVEN, P. H.; EVERT, R. F.; EICHHORN, S. E. Biologia vegetal, 5 ed. Rio de Janeiro: Guanabara Koogan, 1996. 728p.

REUTHER, W. Cimate and citrus beharvior. In: REUTHER, W; BATCHELOR, L. D.; WEBBER, H. J. (Ed.) The citrus industry. Riverside: University of California Press, 1973. v.3, p.280-337.

ROCHA, A. C.; TAVARES, E. D.; SANDRINI, M.; PAIVA, R.; CARVALHO, S. A. Época $e$ intensidade de florescimento e fixação de frutos segundo a distribuição pelos quadrantes em laranjeiras. Pesquisa Agropecuária Brasileira, Brasília, v.25, n.1, p.85-88, 1990. 
SAIDHA, T.; GOLDSCHMIDT, E. E.; MONSELISE, S. P. Endogenous cytokikins of developing 'Shamouti' orange fruits derived from leafy and leafless inflorescensces. Scientia Horticulturae, v. 26, p. 35-41, 1985.

SAUER, M. R. The growth of orange shoots. Australian Journal of Agricultural Research, v.2, p.105-117, 1951.

SAUNT, J. Citrus varieties of the world. Norwich: Sinclair, 1990. 126p.

SentelhAS, P. C.; COELhO FILHO, M. A.; PEREIRA, A. R. Método agrometeorológico de estimativa da época mais adequada para a indução floral do limão 'Tahiti' no Estado de São Paulo. In: CONGRESSO BRASILEIRO DE AGROMETEOROLOGIA, 10. Piracicaba, 1997. Anais., Piracicaba: Sociedade Brasileira de Agrometeorologia, 1997. p.41-43. ๑

SENTELHAS, P. C.; PEREIRA, A. R.; MARIN, F. R.; MARCHI, J. L. Agroclimatic method to determine maturity zones of avocado and citrus in the state of São Paulo, Brasil. In: CONGRESSO BRASILEIRO DE FRUTICULTURA, 14.; REUNIÃO INTERAMERICANA DE HORTICULTURA TROPICAL, 42. Curitiba, 1996. Resumos., Curitiba: Sociedade Brasileira de Fruticultura, 1996. p.449.

SILVA, M. L. M. da. Colheita na estressafra. In: FNP CONSULTORIA \& COMÉRCIO. Agrianual 99: anuário da agricultura brasileira. São Paulo, 1999. p.278.

SOUTHWICK, S. M.; DAVENPORT, T. L. Characterization of water stress and low temperature effects on flower induction in citrus. Plant Physiology, v.81, p.26-29, 1986. 
SPONSEL, V. M. Gibberellin biosynthesis and metabolism. In: DAVIES, P. J. (Ed.) Plant hormones, physiology, biochemistry and molecular biology. Dordrecht: Kluwer Academic,1995. p.66-97.

SPÓSITO, M. B.; CASTRO, P. R. C.; AGUSTII, M. Alternância de produção em citros. Laranja, v.19, n.2, p.293-304, 1998.

STUCHI, E. S.; CYRILLO, F. L. L. Lima ácida 'Tahiti'. Jaboticabal. Funep, 1998. 35p.

TALON, M.; TADEO, F. R.; BEM-CHEIKH, W.; GOMEZ-CADENAS, A.; MEHOUACHI, J.; PÉREZ-BOTELLA, J.; PRIMO-MILLO, E. Hormonal regulation of fruit set and abscission in citrus: classical concepts and new evidence. Acta Horticulturae, n. 463, p. 209-217, 1997.

TALON, M.; ZACARIAS, L.; PRIMO-MILLO, E. Gibberellins and parthenocarpic ability in development ovaries of seedless mandarins. Plant Physiology, v.99, p.1575-1581, 1992.

TALON, M.; ZACARIAS, L.; PRIMO-MILLO, E. Hormonal changes associated with fruit set and development in mandarins differing in their parthenocarpic ability. Plant Physiology, v.79, p.400-406, 1990.

TEÓFILO, J. E. M. Aspectos da citricultura californiana. Citricultura Atual, v. 1, n.4, p.8-9, jun. 1998.

TOMINAGA, S. GA sprays delay and reduce physiological fruit drop Ponkan mandarin (Citrus reticulata Blanco). Acta Horticulturae, n. 463, p.301-306, 1997. 
VIDAL-TORRADO, P.; SPAROVEK, G. Mapa pedológico detalhado do campus "Luiz de Queiroz". Piracicaba: ESALQ, 1993. Escala 1:10.000.

VOLPE, C. A . Fenologia dos citros. In: SEMINÁRIO INTERNACIONAL DE CITROS, 2. Bebedouro, 1992. Anais., Campinas: Fundação Cargill, 1992. p.107-120.

WILTBANK, W.; KREZDORN, A . H. Determination of gibberellins in ovaries and young fruits of navel oranges and their correlation with fruit growth, Journal of the American Society for Horticultural Science, v.94, p.195-201, 1969.

ZUCCONI, F. Peach fruit abscission: the mode of action of thinning agents. Acta Horticulturae, n.80, p.245-255, 1978. 


\section{ANEXO}

Experimento 1.

Dados meteorológicos relativos ao período compreendido entre a antese (22 de outubro de 1997) e a maturação dos frutos (6 de fevereiro de 1998).

TABELA 1 - Dados diários de temperatura máxima, mínima e média, umidade relativa média, precipitação e graus-dias, para o mês de outubro de 1997, Piracicaba-SP.

\begin{tabular}{|c|c|c|c|c|c|c|}
\hline$\overline{\mathrm{Dia}}$ & temp ${ }^{\circ} \mathrm{C}$ & & UR med & Precip. & Média ${ }^{\circ} \mathrm{C}$ & graus-dia \\
\hline & máx & mín & $\%$ & $\mathrm{Mm}$ & máx+mín/2 & méd.-13o.C \\
\hline 22 & 25,45 & 15,88 & 82,5 & 0 & 20,7 & 7,7 \\
\hline 23 & 28 & 14,61 & 75,7 & 0 & 21,3 & 8,3 \\
\hline 24 & 29,62 & 14,96 & 75,4 & 0 & 22,3 & 9,3 \\
\hline 25 & 27,6 & 17,51 & 86,8 & 4,6 & 22,6 & 9,6 \\
\hline 26 & 24,81 & 17,5 & 94,8 & 5,4 & 21,2 & 8,2 \\
\hline 27 & 30,12 & 16,32 & 79,9 & 0 & 23,2 & 10,2 \\
\hline 28 & 34,1 & 17,61 & 71,7 & 0 & 25,9 & 12,9 \\
\hline 29 & 36,2 & 18,87 & 66,71 & 0 & 25,3 & 12,3 \\
\hline 30 & 34,54 & 20,94 & 74,7 & 1,8 & 25,7 & 12,7 \\
\hline 31 & 31,81 & 20,16 & 84,6 & 0,1 & 25,0 & 12,0 \\
\hline média & 30,2 & 17,4 & & & 23,8 & \\
\hline total & & & & 238,3 & & 103,1 \\
\hline
\end{tabular}


TABELA 2 - Dados diários de temperatura máxima, mínima e média, umidade relativa média, precipitação e graus-dias, para o mês de novembro de 1997 , Piracicaba-SP.

\begin{tabular}{|c|c|c|c|c|c|c|}
\hline Dia & temp ${ }^{\circ} \mathrm{C}$ & & UR med & Precip. & média ${ }^{\circ} \mathrm{C}$ & graus-dia \\
\hline & máx & min & $\%$ & $\mathrm{Mm}$ & $\operatorname{máx}+\min / 2$ & méd-13o.C \\
\hline 1 & 35,53 & 20,94 & 76,2 & 23,1 & 26,2 & 13,2 \\
\hline 2 & 34,51 & 20,3 & 75,6 & 0 & 26,4 & 13,4 \\
\hline 3 & 31,5 & 22,33 & 79,3 & 0 & 26,9 & 13,9 \\
\hline 4 & 28,86 & 21,63 & 78,3 & 0 & 25,2 & 12,2 \\
\hline 5 & 34,45 & 20,92 & 75,8 & 0 & 25,7 & 12,7 \\
\hline 6 & 30,2 & 21,04 & 84,8 & 2,9 & 25,6 & 12,6 \\
\hline 7 & 32,77 & 20,96 & 85,7 & 1,4 & 26,9 & 13,9 \\
\hline 8 & 32,55 & 21,33 & 77,3 & 0 & 26,9 & 13,9 \\
\hline 9 & 34,91 & 19,76 & 68,82 & 0 & 27,3 & 14,3 \\
\hline 10 & 37,66 & 19,25 & 58,27 & 0 & 27,5 & 14,5 \\
\hline 11 & 37,83 & 21,07 & 62,42 & 0 & 27,5 & 14,5 \\
\hline 12 & 33,68 & 21,76 & 74,8 & 3,8 & 26,7 & 13,7 \\
\hline 13 & 33,66 & 21,39 & 79,2 & 4,4 & 26,5 & 13,5 \\
\hline 14 & 31,8 & 20,26 & 82,9 & 0 & 24,0 & 11,0 \\
\hline 15 & 26,88 & 17,55 & 91,4 & 18,6 & 22,2 & 9,2 \\
\hline 16 & 27,77 & 19,14 & 95,1 & 19,2 & 23,5 & 10,5 \\
\hline 17 & 26,79 & 19,85 & 96,5 & 29,4 & 23,3 & 10,3 \\
\hline 18 & 24,91 & 19,19 & 100 & 28,7 & 22,1 & 9,1 \\
\hline 19 & 25,34 & 18,52 & 85,9 & 0,8 & 21,9 & 8,9 \\
\hline 20 & 30,79 & 16,12 & 78,2 & 0 & 23,5 & 10,5 \\
\hline 21 & 33,26 & 17,7 & 85,8 & 3 & 25,5 & 12,5 \\
\hline 22 & 31,3 & 19,67 & 85,4 & 6,1 & 25,5 & 12,5 \\
\hline 23 & 32,14 & 21,53 & 88,6 & 0 & 25,8 & 12,8 \\
\hline 24 & 32,41 & 20,07 & 89,1 & 53,9 & 25,2 & 12,2 \\
\hline 25 & 28,17 & 20,03 & 84,2 & 0,3 & 24,1 & 11,1 \\
\hline 26 & 25,73 & 20,24 & 95,9 & 9,9 & 23,0 & 10,0 \\
\hline 27 & 26,45 & 20,18 & 97,7 & 35,3 & 23,3 & 10,3 \\
\hline 28 & 22,5 & 17,92 & 93,3 & 3,5 & 20,2 & 7,2 \\
\hline 29 & 28,39 & 16,13 & 74,7 & 0 & 22,3 & 9,3 \\
\hline 30 & 30,17 & 17,32 & 77,1 & 0 & 23,7 & 10,7 \\
\hline média & 30,76 & 19,80 & & & 25,28 & \\
\hline total & & & & 244,3 & & 354,5 \\
\hline
\end{tabular}


TABELA 3 - Dados diários de temperatura máxima, mínima e média, umidade relativa média, precipitação e graus-dias, para o mês de dezembro de 1997 , Piracicaba-SP.

\begin{tabular}{|c|c|c|c|c|c|c|}
\hline Dia & temp ${ }^{\circ} \mathrm{C}$ & & UR med & Precip. & média ${ }^{\circ} \mathrm{C}$ & Graus-dia \\
\hline & máx & mín & $\%$ & $\mathrm{Mm}$ & máx+mín/2 & méd-13o.C \\
\hline 1 & 26,32 & 18,88 & 93,8 & 4,8 & 22,6 & 9,6 \\
\hline 2 & 29,08 & 19,89 & 87,8 & 7,7 & 24,5 & 11,5 \\
\hline 3 & 30,56 & 19,08 & 87,2 & 0,1 & 24,8 & 11,8 \\
\hline 4 & 26,28 & 19,46 & 97,8 & 21,9 & 22,9 & 9,9 \\
\hline 5 & 31,74 & 18,83 & 81,3 & 0,1 & 25,3 & 12,3 \\
\hline 6 & 34,3 & 19,7 & 75 & 0 & 25,0 & 12,0 \\
\hline 7 & 30,17 & 20,82 & 90 & 21 & 25,5 & 12,5 \\
\hline 8 & 30,11 & 20,7 & 90,1 & 0,1 & 25,4 & 12,4 \\
\hline 9 & 29,83 & 19,59 & 79,1 & 0 & 24,7 & 11,7 \\
\hline 10 & 32,22 & 18,41 & 69,1 & 0 & 25,3 & 12,3 \\
\hline 11 & 33,17 & 17,31 & 73,7 & 0 & 25,2 & 12,2 \\
\hline 12 & 31,95 & 19,05 & 84,1 & 0,2 & 25,5 & 12,5 \\
\hline 13 & 31,71 & 20,71 & 90,1 & 0,2 & 26,2 & 13,2 \\
\hline 14 & 31,92 & 20,66 & 85,2 & 18,6 & 26,3 & 13,3 \\
\hline 15 & 29,83 & 21,99 & 83,5 & 0,8 & 25,9 & 12,9 \\
\hline 16 & 31,94 & 19,12 & 79,7 & 0 & 25,5 & 12,5 \\
\hline 17 & 28,09 & 18,35 & 76,6 & 0 & 23,2 & 10,2 \\
\hline 18 & 29,07 & 19,06 & 80,1 & 0 & 24,1 & 11,1 \\
\hline 19 & 31 & 19,44 & 83 & 1 & 25,2 & 12,2 \\
\hline 20 & 33,03 & 19,48 & 74,8 & 0 & 26,3 & 13,3 \\
\hline 21 & 32,57 & 20,17 & 82,6 & 13,3 & 26,4 & 13,4 \\
\hline 22 & 34,65 & 19,74 & 76,2 & 0 & 26,2 & 13,2 \\
\hline 23 & 35,92 & 21,03 & 69,24 & 0 & 26,5 & 13,5 \\
\hline 24 & 36,64 & 21 & 75,4 & 83,4 & 26,8 & 13,8 \\
\hline 25 & 34,41 & 19,75 & 83 & 9,2 & 27,1 & 14,1 \\
\hline 26 & 34,11 & 20,21 & 79,7 & 0,2 & 27,2 & 14,2 \\
\hline 27 & 34,98 & 22,24 & 77,6 & 0 & 27,6 & 14,6 \\
\hline 28 & 33,75 & 22,43 & 83,2 & 0,3 & 27,1 & 14,1 \\
\hline 29 & 32,66 & 21,05 & 80,1 & 0 & 26,9 & 13,9 \\
\hline 30 & 33,63 & 20,51 & 86,5 & 8,2 & 26,1 & 13,1 \\
\hline 31 & 33,86 & 19,66 & 80,2 & 0 & 26,8 & 13,8 \\
\hline média & 31,92 & 19,95 & & & 25,93 & \\
\hline total & & & & 191,1 & & 390,9 \\
\hline
\end{tabular}


TABELA 4 - Dados diários de temperatura máxima, mínima e média, umidade relativa média, precipitação e graus-dias, para o mês de janeiro de 1998, Piracicaba-SP.

\begin{tabular}{|c|c|c|c|c|c|c|}
\hline Dia & temp ${ }^{\circ} \mathrm{C}$ & & UR med & Precip. & Média ${ }^{\circ} \mathrm{C}$ & graus dias \\
\hline & máx & mín & $\%$ & $\overline{\mathrm{Mm}}$ & $($ tmáx+tmín)/2 & méd-1 $13^{\circ} \mathrm{C}$ \\
\hline 1 & 35,05 & 21,36 & 80,6 & 0,0 & 27,2 & 14,2 \\
\hline 2 & 34,58 & 21,34 & 75,3 & 0,0 & 27,0 & 14,0 \\
\hline 3 & 32,79 & 22,04 & 80,4 & 0,3 & 27,4 & 14,4 \\
\hline 4 & 32,69 & 21,84 & 81,7 & 0,0 & 27,3 & 14,3 \\
\hline 5 & 35,18 & 21,43 & 78,4 & 0,0 & 26,3 & 13,3 \\
\hline 6 & 35,02 & 22,37 & 79,6 & 0,0 & 26,7 & 13,7 \\
\hline 7 & 30,46 & 21,78 & 90,4 & 0,4 & 26,1 & 13,1 \\
\hline 8 & 22,31 & 19,24 & 95,7 & 11,2 & 20,8 & 7,8 \\
\hline 9 & 22,89 & 18,51 & 87,1 & 0,4 & 20,7 & 7,7 \\
\hline 10 & 26,35 & 19,33 & 87,8 & 0,0 & 22,8 & 9,8 \\
\hline 11 & 32,8 & 18,06 & 83 & 0,2 & 25,4 & 12,4 \\
\hline 12 & 32,92 & 19,33 & 85,3 & 5,5 & 26,1 & 13,1 \\
\hline 13 & 30,95 & 19,73 & 83,5 & 0,0 & 25,3 & 12,3 \\
\hline 14 & 32,03 & 21,63 & 78,1 & 0,0 & 26,8 & 13,8 \\
\hline 15 & 30,69 & 21,49 & 87,3 & 0,5 & 26,1 & 13,1 \\
\hline 16 & 30,54 & 18,81 & 90,8 & 13,2 & 24,7 & 11,7 \\
\hline 17 & 30,83 & 18,95 & 89,5 & 28,1 & 24,9 & 11,9 \\
\hline 18 & 32,56 & 19,68 & 85,8 & 0,0 & 25,1 & 12,1 \\
\hline 19 & 33,81 & 19,63 & 81,1 & 0,0 & 26,7 & 13,7 \\
\hline 20 & 33,05 & 19,59 & 79,9 & 0,4 & 26,3 & 13,3 \\
\hline 21 & 32,9 & 20,43 & 77,8 & 0,0 & 26,7 & 13,7 \\
\hline 22 & 32,31 & 19,9 & 75,8 & 0,0 & 26,1 & 13,1 \\
\hline 23 & 33,96 & 20,41 & 78,7 & 0,0 & 27,2 & 14,2 \\
\hline 24 & 35 & 21,76 & 74,2 & 0,0 & 27,4 & 14,4 \\
\hline 25 & 32,74 & 21,41 & 90,8 & 32,8 & 27,1 & 14,1 \\
\hline 26 & 34,11 & 21,19 & 85,7 & 0,0 & 27,7 & 14,7 \\
\hline 27 & 34,47 & 22,36 & 79,4 & 0,0 & 27,4 & 14,4 \\
\hline 28 & 34,59 & 22,87 & 88,8 & 6,8 & 27,7 & 14,7 \\
\hline 29 & 32,25 & 22,12 & 87,9 & 0,1 & 26,2 & 13,2 \\
\hline 30 & 34,65 & 22,37 & 82,7 & 0,0 & 27,5 & 14,5 \\
\hline 31 & 35,21 & 21,66 & 81,2 & 0,0 & 27,4 & 14,4 \\
\hline média & 32,25 & 20,73 & & & 26,49 & \\
\hline total & & & & 99,9 & & 405,2 \\
\hline
\end{tabular}


TABELA 5 - Dados diários de temperatura máxima, mínima e média, umidade relativa média, precipitação e graus-dias, para o mês de fevereiro de 1998, Piracicaba-SP.

\begin{tabular}{ccccccc}
\hline Dia & temp $^{\circ} \mathrm{C}$ & & UR med & Precip. & média ${ }^{\circ} \mathrm{C}$ & graus-dia \\
\hline & máx & mín & $\%$ & Mm & máx+min/2 & méd-13 ${ }^{\circ} \mathrm{C}$ \\
\hline 1 & 32,0 & 22,5 & 90 & 5,8 & 27,25 & 14,25 \\
2 & 33,5 & 21,6 & 81 & 0,1 & 27,55 & 14,55 \\
3 & 32,8 & 21,5 & 82 & 0,0 & 27,15 & 14,15 \\
4 & 33,8 & 20,6 & 89 & 33,2 & 27,20 & 14,2 \\
5 & 34,1 & 20,6 & 85 & 8,1 & 27,35 & 14,35 \\
6 & 31,4 & 21,0 & 86 & 0,1 & 26,20 & 13,2 \\
\hline média & 32,93 & 21,30 & & & 27,12 & \\
\hline total & & & & 47,3 & & 84,7 \\
\hline
\end{tabular}




\section{Experimento 2.}

Dados meteorológicos relativos ao período compreendido entre a antese (15 de março de 1998) e a maturação dos frutos (28 de agosto de 1998).

TABELA 6 - Dados diários de temperatura máxima, mínima e média, umidade relativa média, precipitação e graus-dias, para o mês de março de 1998, Piracicaba-SP.

\begin{tabular}{ccccccc}
\hline Dia & Temp $^{\circ} \mathrm{C}$ & & UR med & Precip. & média ${ }^{\circ} \mathrm{C}$ & Graus-dia \\
\hline & máx & mín & $\%$ & Mm & máx+mín/2 & méd-13 ${ }^{\circ} \mathrm{C}$ \\
\hline 15 & 28,6 & 20,7 & 84 & 0,0 & 24,7 & 11,7 \\
16 & 28,4 & 18,7 & 81 & 0,0 & 23,6 & 10,6 \\
17 & 28,7 & 18,1 & 75 & 0,0 & 23,4 & 10,4 \\
18 & 28,8 & 18,4 & 87 & 0,0 & 23,6 & 10,6 \\
19 & 30,6 & 19,7 & 88 & 10,1 & 23,2 & 10,2 \\
20 & 31,8 & 20,5 & 81 & 0,0 & 24,2 & 11,2 \\
21 & 31,1 & 21,2 & 87 & 0,0 & 24,2 & 11,2 \\
22 & 28,1 & 19,4 & 91 & 22,2 & 21,8 & 8,8 \\
23 & 30,0 & 19,9 & 88 & 0,0 & 25,0 & 12,0 \\
24 & 32,8 & 20,0 & 83 & 0,0 & 24,4 & 11,4 \\
25 & 29,4 & 21,7 & 89 & 0,9 & 24,6 & 11,6 \\
26 & 28,8 & 17,8 & 76 & 0,0 & 23,3 & 10,3 \\
27 & 30,0 & 14,9 & 84 & 0,0 & 22,5 & 9,5 \\
28 & 30,9 & 18,6 & 86 & 21,8 & 24,8 & 11,8 \\
29 & 31,4 & 19,1 & 90 & 11,9 & 24,3 & 11,3 \\
30 & 26,4 & 20,5 & 97 & 0,0 & 23,5 & 10,5 \\
31 & 31,4 & 19,5 & 89 & 6,0 & 24,3 & 10,3 \\
& & & & & & \\
\hline média & 29,8 & 19,3 & \multicolumn{5}{c}{24,6} & \\
\hline total & \multicolumn{7}{c}{72,9} & & 183,4 \\
\hline
\end{tabular}


TABELA 7 - Dados diários de temperatura máxima, mínima e média, umidade relativa média, precipitação, graus-dias, para o mês de abril de 1998, Piracicaba-SP.

\begin{tabular}{ccccccc}
\hline Dia & temp. ${ }^{\circ} \mathrm{C}$ & \multicolumn{6}{c}{ UR med } & Precip. & média ${ }^{\circ} \mathrm{C}$ & graus-dia \\
\hline & máx & mín & $\%$ & Mm & máx/mín/2 & méd-13 ${ }^{\circ} \mathrm{C}$ \\
\hline 1 & 29,6 & 19,3 & 91 & 1,5 & 22,5 & 9,5 \\
2 & 26,9 & 17,0 & 79 & 0,0 & 22,0 & 9,0 \\
3 & 24,3 & 15,9 & 71 & 0,0 & 20,1 & 7,1 \\
4 & 24,2 & 14,4 & 70 & 0,0 & 19,3 & 6,3 \\
5 & 25,1 & 15,0 & 78 & 0,0 & 20,1 & 7,1 \\
6 & 30,0 & 15,0 & 75 & 0,0 & 22,5 & 9,5 \\
7 & 22,3 & 16,6 & 92 & 1,5 & 19,5 & 6,5 \\
8 & 31,4 & 16,5 & 83 & 24,6 & 22,0 & 9,0 \\
9 & 23,9 & 17,4 & 95 & 0,0 & 20,7 & 7,7 \\
10 & 29,1 & 19,8 & 83 & 0,0 & 24,5 & 11,5 \\
11 & 31,3 & 16,2 & 84 & 0,0 & 23,8 & 10,8 \\
12 & 32,2 & 18,5 & 83 & 0,0 & 23,4 & 10,4 \\
13 & 32,9 & 18,5 & 89 & 0,0 & 23,7 & 10,7 \\
14 & 32,8 & 18,5 & 78 & 0,0 & 23,7 & 10,7 \\
15 & 33,4 & 18,3 & 76 & 0,0 & 23,9 & 10,9 \\
16 & 32,3 & 19,2 & 82 & 8,4 & 23,8 & 10,8 \\
17 & 28,2 & 20,8 & 89 & 3,7 & 24,5 & 11,5 \\
18 & 25,2 & 16,1 & 81 & 4,3 & 20,7 & 7,7 \\
19 & 25,9 & 12,0 & 70 & 0,0 & 19,0 & 6,0 \\
20 & 27,1 & 10,7 & 75 & 0,0 & 18,9 & 5,9 \\
21 & 30,8 & 13,2 & 81 & 0,0 & 22,0 & 9,0 \\
22 & 32,6 & 16,7 & 80 & 0,0 & 24,7 & 11,7 \\
23 & 32,7 & 18,3 & 67 & 0,0 & 23,5 & 10,5 \\
24 & 29,1 & 20,0 & 77 & 0,0 & 23,6 & 10,6 \\
25 & 28,7 & 17,8 & 77 & 0,0 & 23,3 & 10,3 \\
26 & 25,9 & 18,2 & 78 & 0,4 & 22,1 & 9,1 \\
27 & 31,5 & 17,2 & 80 & 8,8 & 22,4 & 9,4 \\
28 & 24,0 & 20,0 & 99 & 8,8 & 22,0 & 9,0 \\
29 & 26,2 & 18,8 & 91 & 4,7 & 20,5 & 7,5 \\
30 & 22,2 & 14,6 & 77 & 0,0 & 18,4 & 5,4 \\
\hline média & 28,4 & 17,0 & & & 22,7 & \\
\hline total & & & & 66,7 & & 260,2 \\
\hline & & & & & &
\end{tabular}


TABELA 8 - Dados diários de temperatura máxima, mínima e média, umidade relativa média, precipitação e graus-dias, para o mês de maio de 1998 , Piracicaba-SP.

\begin{tabular}{|c|c|c|c|c|c|c|}
\hline Dia & temp ${ }^{\circ} \mathrm{C}$ & & UR med & Precip. & média ${ }^{\circ} \mathrm{C}$ & graus-dia \\
\hline & máx & mín & $\%$ & $\mathrm{Mm}$ & máx+mín/2 & méd $-13^{\circ} \mathrm{C}$ \\
\hline$\overline{1}$ & 22,3 & 10,0 & 77 & 0,0 & 16,2 & 3,2 \\
\hline 2 & 24,3 & 9,6 & 76 & 0,0 & 17,0 & 4,0 \\
\hline 3 & 20,7 & 13,3 & 94 & 10,6 & 17,0 & 4,0 \\
\hline 4 & 19,3 & 15,7 & 100 & 28,8 & 17,5 & 4,5 \\
\hline 5 & 22,9 & 15,1 & 86 & 0,0 & 19,0 & 6,0 \\
\hline 6 & 23,6 & 14,0 & 82 & 0,0 & 18,8 & 5,8 \\
\hline 7 & 23,4 & 11,9 & 81 & 0,0 & 17,7 & 4,7 \\
\hline 8 & 24,0 & 9,5 & 74 & 0,0 & 16,8 & 3,8 \\
\hline 9 & 25,4 & 9,6 & 79 & 0,0 & 17,5 & 4,5 \\
\hline 10 & 27,1 & 8,4 & 77 & 0,0 & 17,8 & 4,8 \\
\hline 11 & 27,5 & 9,1 & 76 & 0,0 & 18,3 & 5,3 \\
\hline 12 & 29,1 & 11,2 & 75 & 0,0 & 18,2 & 5,2 \\
\hline 13 & 29,2 & 11,0 & 72 & 0,0 & 20,1 & 7,1 \\
\hline 14 & 28,7 & 12,5 & 72 & 0,0 & 20,6 & 7,6 \\
\hline 15 & 26,0 & 14,4 & 86 & 0,2 & 20,2 & 7,2 \\
\hline 16 & 20,4 & 15,2 & 94 & 3,1 & 17,8 & 4,8 \\
\hline 17 & 22,3 & 10,8 & 75 & 0,0 & 16,6 & 3,6 \\
\hline 18 & 23,4 & 11,5 & 81 & 0,0 & 17,5 & 4,5 \\
\hline 19 & 26,1 & 13,7 & 79 & 0,0 & 19,9 & 6,9 \\
\hline 20 & 28,4 & 12,7 & 82 & 0,0 & 20,6 & 7,6 \\
\hline 21 & 28,8 & 12,9 & 77 & 0,0 & 20,9 & 7,9 \\
\hline 22 & 27,8 & 12,1 & 82 & 0,0 & 20,0 & 7,0 \\
\hline 23 & 27,9 & 12,9 & 80 & 0,0 & 20,4 & 7,4 \\
\hline 24 & 28,0 & 17,4 & 70 & 0,0 & 21,7 & 8,7 \\
\hline 25 & 28,6 & 17,2 & 74 & 0,0 & 20,9 & 7,9 \\
\hline 26 & 27,8 & 15,2 & 71 & 13,7 & 21,5 & 8,5 \\
\hline 27 & 24,6 & 16,0 & 96 & 9,9 & 20,3 & 7,3 \\
\hline 28 & 25,4 & 14,1 & 85 & 0,1 & 19,8 & 6,8 \\
\hline 29 & 17,3 & 14,1 & 98 & 21,7 & 15,7 & 2,7 \\
\hline 30 & 21,6 & 15,0 & 92 & 9,2 & 18,3 & 5,3 \\
\hline 31 & 21,4 & 10,7 & 80 & 0,3 & 16,1 & 3,1 \\
\hline média & 24,9 & 12,8 & & & 18,9 & \\
\hline total & & & & 97,6 & & 177,1 \\
\hline
\end{tabular}


TABELA 9 - Dados diários de temperatura máxima, mínima e média, umidade relativa média, precipitação e graus-dias, para o mês de junho de 1998, Piracicaba-SP.

\begin{tabular}{ccccccc}
\hline Dia & temp $^{\circ} \mathrm{C}$ & & UR med & Precip. & média ${ }^{\circ} \mathrm{C}$ & graus-dias \\
\hline & máx & mín & $\%$ & Mm & máx+mín/2 & méd-13 ${ }^{\circ} \mathrm{C}$ \\
\hline 1 & 24,2 & 8,8 & 84 & 0,0 & 16,5 & 3,5 \\
2 & 24,3 & 10,0 & 91 & 0,0 & 17,2 & 4,2 \\
3 & 24,3 & 9,5 & 93 & 0,0 & 16,9 & 3,9 \\
4 & 23,6 & 8,7 & 90 & 0,0 & 16,2 & 3,2 \\
5 & 22,7 & 8,7 & 82 & 0,0 & 15,7 & 2,7 \\
6 & 24,7 & 8,1 & 84 & 0,0 & 16,4 & 3,4 \\
7 & 24,7 & 9,1 & 79 & 0,0 & 16,9 & 3,9 \\
8 & 24,8 & 7,0 & 86 & 0,0 & 15,9 & 2,9 \\
9 & 25,1 & 7,2 & 91 & 0,0 & 16,2 & 3,2 \\
10 & 27,1 & 8,5 & 93 & 0,0 & 17,8 & 4,8 \\
11 & 24,1 & 10,9 & 89 & 0,0 & 17,5 & 4,5 \\
12 & 20,8 & 12,1 & 83 & 0,0 & 16,5 & 3,5 \\
13 & 22,5 & 9,1 & 84 & 0,0 & 15,8 & 2,8 \\
14 & 24,8 & 12,2 & 79 & 0,0 & 18,5 & 5,5 \\
15 & 24,5 & 10,4 & 93 & 0,0 & 17,5 & 4,5 \\
16 & 23,4 & 9,5 & 85 & 0,0 & 16,5 & 3,5 \\
17 & 27,0 & 9,2 & 84 & 0,0 & 18,1 & 5,1 \\
18 & 28,3 & 13,0 & 82 & 17,8 & 20,7 & 7,7 \\
19 & 21,1 & 14,4 & 97 & 0,0 & 17,8 & 4,8 \\
20 & 22,3 & 10,2 & 88 & 0,0 & 16,3 & 3,3 \\
21 & 22,2 & 8,1 & 84 & 0,0 & 15,2 & 2,2 \\
22 & 25,0 & 8,6 & 86 & 0,0 & 16,8 & 3,8 \\
23 & 27,8 & 9,7 & 87 & 0,0 & 18,8 & 5,8 \\
24 & 24,4 & 11,0 & 88 & 8,8 & 17,7 & 4,7 \\
25 & 18,6 & 13,1 & 79 & 0,0 & 15,9 & 2,9 \\
26 & 22,4 & 7,3 & 80 & 0,0 & 14,9 & 1,9 \\
27 & 24,2 & 8,9 & 85 & 0,0 & 16,6 & 3,6 \\
28 & 25,0 & 11,7 & 89 & 0,0 & 18,4 & 5,4 \\
29 & 24,0 & 10,4 & 93 & 0,0 & 17,2 & 4,2 \\
30 & 25,7 & 10,5 & 90 & 0,0 & 18,1 & 5,1 \\
\hline média & 24,1 & 9,9 & & & 17,0 & \\
\hline total & & & & 26,6 & & 119,8 \\
\hline & & & & & &
\end{tabular}


TABELA 10 - Dados diários de temperatura máxima, mínima e média, umidade relativa média, precipitação e graus-dias, para o mês de julho de 1998, Piracicaba-SP.

\begin{tabular}{|c|c|c|c|c|c|c|}
\hline Dia & temp ${ }^{\circ} \mathrm{C}$ & & UR med & precip. & média ${ }^{\circ} \mathrm{C}$ & graus-dia \\
\hline & máx & mín & $\%$ & $\mathrm{~mm}$ & máx+mín/2 & méd-13 $1{ }^{\circ} \mathrm{C}$ \\
\hline 1 & 28,1 & 10,4 & 87 & 0,0 & 19,3 & 6,3 \\
\hline 2 & 28,7 & 11,1 & 80 & 0,0 & 19,9 & 6,9 \\
\hline 3 & 25,3 & 11,9 & 86 & 0,0 & 18,6 & 5,6 \\
\hline 4 & 25,9 & 11,4 & 80 & 0,0 & 18,7 & 5,7 \\
\hline 5 & 26,1 & 10,7 & 85 & 0,0 & 18,4 & 5,4 \\
\hline 6 & 24,8 & 10,2 & 89 & 0,0 & 17,5 & 4,5 \\
\hline 7 & 28,5 & 9,5 & 83 & 0,0 & 19,0 & 6,0 \\
\hline 8 & 29,5 & 9,8 & 69 & 0,0 & 19,7 & 6,7 \\
\hline 9 & 19,3 & 11,5 & 93 & 6,2 & 15,4 & 2,4 \\
\hline 10 & 18,4 & 8,3 & 81 & 0,0 & 13,4 & 0,4 \\
\hline 11 & 20,3 & 10,4 & 81 & 0,0 & 15,4 & 2,4 \\
\hline 12 & 19,2 & 9,0 & 83 & 0,0 & 14,1 & 1,1 \\
\hline 13 & 20,8 & 8,6 & 81 & 0,0 & 14,7 & 1,7 \\
\hline 14 & 23,7 & 7,1 & 79 & 0,0 & 15,4 & 2,4 \\
\hline 15 & 25,1 & 8,4 & 79 & 0,0 & 16,8 & 3,8 \\
\hline 16 & 24,9 & 6,7 & 76 & 0,0 & 15,8 & 2,8 \\
\hline 17 & 27,0 & 5,5 & 66 & 0,0 & 16,3 & 3,3 \\
\hline 18 & 28,9 & 7,9 & 64 & 0,0 & 18,4 & 5,4 \\
\hline 19 & 21,5 & 14,4 & 95 & 7,7 & 18,0 & 5,0 \\
\hline 20 & 24,0 & 13,8 & 94 & 0,0 & 18,9 & 5,9 \\
\hline 21 & 31,1 & 12,2 & 78 & 0,0 & 21,7 & 8,7 \\
\hline 22 & 29,0 & 13,1 & 89 & 0,0 & 21,1 & 8,1 \\
\hline 23 & 29,3 & 11,6 & 85 & 0,0 & 20,5 & 7,5 \\
\hline 24 & 26,2 & 12,9 & 85 & 0,0 & 19,6 & 6,6 \\
\hline 25 & 27,6 & 13,3 & 80 & 0,0 & 20,5 & 7,5 \\
\hline 26 & 27,8 & 13,2 & 69 & 0,0 & 20,5 & 7,5 \\
\hline 27 & 30,4 & 12,0 & 74 & 0,0 & 21,2 & 8,2 \\
\hline 28 & 30,6 & 13,8 & 71 & 0,0 & 22,2 & 9,2 \\
\hline 29 & 30,4 & 13,4 & 73 & 0,0 & 21,9 & 8,9 \\
\hline 30 & 22,6 & 12,8 & 84 & 0,0 & 17,7 & 4,7 \\
\hline 31 & 27,6 & 10,5 & 80 & 0,0 & 19,1 & 6,1 \\
\hline média & 25,9 & 10,8 & & & 18,4 & \\
\hline total & & & & 13,9 & & 166,0 \\
\hline
\end{tabular}


TABELA 11 - Dados diários de temperatura máxima, mínima e média, umidade relativa média, precipitação e graus-dias, para o mês de agosto de 1998, Piracicaba-SP.

\begin{tabular}{ccccccc}
\hline Dia & temp ${ }^{\circ} \mathrm{C}$ & & UR med & precip. & média ${ }^{\circ} \mathrm{C}$ & graus-dia \\
\hline & máx & mín & $\%$ & mm & máx+mín/2 & méd-13 ${ }^{\circ} \mathrm{C}$ \\
\hline 1 & 27,4 & 11,6 & 63 & 0,0 & 19,5 & 6,5 \\
2 & 19,4 & 13,3 & 92 & 6,6 & 16,4 & 3,4 \\
3 & 26,5 & 11,5 & 80 & 0,0 & 19,0 & 6,0 \\
4 & 29,7 & 10,5 & 80 & 3,2 & 20,1 & 7,1 \\
5 & 20,6 & 11,4 & 98 & 4,1 & 16,0 & 3,0 \\
6 & 21,7 & 11,8 & 92 & 0,0 & 16,8 & 3,8 \\
7 & 23,4 & 12,2 & 83 & 0,0 & 17,8 & 4,8 \\
8 & 24,3 & 13,7 & 85 & 0,0 & 19,0 & 6,0 \\
9 & 19,3 & 16,4 & 99 & 3,9 & 17,9 & 4,9 \\
10 & 24,3 & 15,5 & 94 & 0,0 & 19,9 & 6,9 \\
11 & 28,0 & 14,2 & 86 & 0,0 & 21,1 & 8,1 \\
12 & 29,6 & 15,0 & 79 & 0,0 & 22,3 & 9,3 \\
13 & 32,7 & 16,5 & 77 & 4,0 & 22,6 & 9,6 \\
14 & 30,1 & 17,8 & 85 & 0,0 & 22,4 & 9,4 \\
15 & 31,9 & 15,9 & 62 & 0,0 & 22,9 & 9,9 \\
16 & 29,3 & 17,8 & 81 & 0,0 & 22,6 & 9,6 \\
17 & 30,9 & 15,1 & 79 & 0,0 & 22,0 & 9,0 \\
18 & 31,2 & 15,8 & 69 & 0,0 & 23,5 & 9,5 \\
19 & 23,6 & 14,9 & 80 & 0,0 & 19,3 & 6,3 \\
20 & 30,6 & 14,0 & 75 & 0,0 & 22,3 & 9,3 \\
21 & 32,5 & 15,1 & 75 & 0,0 & 21,8 & 8,8 \\
22 & 27,7 & 14,8 & 86 & 0,0 & 21,3 & 8,3 \\
23 & 29,5 & 14,3 & 77 & 0,0 & 21,9 & 8,9 \\
24 & 31,8 & 16,4 & 53 & 0,0 & 21,1 & 8,1 \\
25 & 33,1 & 15,1 & 52 & 0,0 & 21,1 & 9,1 \\
26 & 33,1 & 14,2 & 55 & 0,0 & 21,7 & 8,7 \\
27 & 26,3 & 16,4 & 59 & 0,0 & 21,4 & 8,4 \\
28 & 25,4 & 13,5 & 69 & 0,0 & 19,5 & 6,5 \\
\hline média & 27,6 & 14,5 & & & 21,0 & \\
\hline total & & & & 21,8 & & 208,7 \\
\hline & & & & & &
\end{tabular}

